\title{
CULICOIDES DA REGIÃO NEOTROPICAL (DIPTERA, CERATOPOGONIDAE). II - OBSERVAÇÕES SÔBRE BIOLOGIA EM CONDIÇÕES NATURAIS *
}

\author{
Oswaldo P. Forattini ** \\ ERnesto X. Rabello*** \\ DinO PATTOLI ****
}

Introdução

A região estudada

Localização

Dados Geográficos

Terreno e vegetação

Caracteres sociais

Clima

Métodos utilizados

Coleta de formas imaturas

Captura de adultos

Observaçōes sôbre criadouros naturais

Dados gerais

Pesquisas em terreno pantanoso ou "mangue"

Pesquisas em coleçôes de água de terrenos sêcos

Pesquisas em buracos de carangueijos

Observações sôbre o comportamento dos adultos

Frequência domiciliar

Hematofagia

Incidência

Influência das marés

Variação estacional

Espécies encontradas

Resumo

Summary

Bibliografia

Entreque para Publicação em 17-6-1958.

* Trabalho da Cadeira de Parasitologia Aplicada e Higiene Rural (Prof. Paulo C. A. Antunes) da Faculdade de Higiene e Saúde Pública da Universidade de São Paulo.

** Assistente e Livre-Docente da Cadeira.

*** Do Departamento de Produção Animal da Secretaria da Agricultura do Estado de São Paulo.

**** Assistente da Cadeira. 


\section{INTRODUÇAO}

O gênero Culicoides inclui pequenos dipteros da familia Ceratopogonidae, bem conhecidos por seu hábito hematófago. Várias são as designações pelas quais eles são conhecidos. No Brasil recebem o nome de "maruins", "mosquitos pólvora" e "mosquitos do mangue". Nos Países hispano-americanos são conhedidos por "jejénes", "polvorines" e "arenillas". Nas regiões de língua inglesa, recebem as designações de "sand flies", "punkies", "no-see-ums" and "biting midges".

Tais insetos chamam a atenção pela hematofagia, tornando-se assim bastante incômodos em algumas regiões e em certas épocas do ano. Isso tem sido observado em várias áreas do Continente Americano, principalmente nas zonas litorâneas. Além disso, algumas espécies foram incriminadas como veiculadoras de agentes etiológicos de moléstias do homem e animais domésticos. Assim pois, entre eles encontram-se os transmissores das filárias Acanthocheilonema perstans e Mansonella ozzardi do homem, do vírus da moléstia africana dos cavalos e da língua azul das ovelhas. Recentemente, Karstad et al. ${ }^{21}$ (1957), trabalhando na Georgia, U.S.A., isolaram o vírus da encefalomielite equina tipo leste, dêsses dipteros. Como se pode ver, ao lado do interêsse econômico, cresce dia a dia a importância dêsses insetos em medicina humana e veterinária.

Os Culicoides foram objeto de estudos, sob o ponto de vista de sua biologia, por parte de muitos autores que procuraram encarar o problema no tríplice aspecto do comportamento das formas imaturas, dos adultos e do contrôle. No nosso meio, os estudos biológicos iniciais, dêsses insetos devem-se a Lutz ${ }^{26,2 \pi}(1912,1913)$ que realizou suas pesquisas nos arredores da cidade do Rio de Janeiro. Lane ${ }^{25}$ (1947), relatou algumas observações sôbre formas imaturas. Como se pode ver, ressalta a escassez de dados sôbre êsse assunto que, além do mais, necessita ser atualizado entre nós. Em vista disso, fomos levados a realizar observações nesse sentido, escolhendo região semelhante à que serviu para os trabalhos de Lutz ${ }^{26,2:}$ $(1912,1913)$, e que é a que rodeia a cidade de São Vicente, no litoral do Estado de São Paulo. São os resultados de tais observações que constituem o objeto do presente trabalho.

Esta publicação representa o complemento à parte Taxonômica dêstes insetos, já impressa no número anterior desta Revista. Assim sendo, encerramos com êste trabalho, os nossos estudos gerais sôbre Culicoides. Acreditamos dever, nesta ocasião, tornar públicos os nossos agradecimentos ao caro mestre e amigo, Prof. John Lane, pela sempre valiosa ajuda e orientação, e a quem a Entomologia brasileira deve tantas e tão destacadas contribuições. A êle pois, dedicamos estas investigações.

Desejamos também, deixar consignados os nossos agradecimentos ao Sr. Orlando de Almeida, entomologista do Serviço de Profilaxia da Malária, pelo valioso auxílio na coleta de material no campo. 
FORATTINI, O. P. \& COLS. - CULICOIDES DA REGIAOO NEOTROPICAL... 3

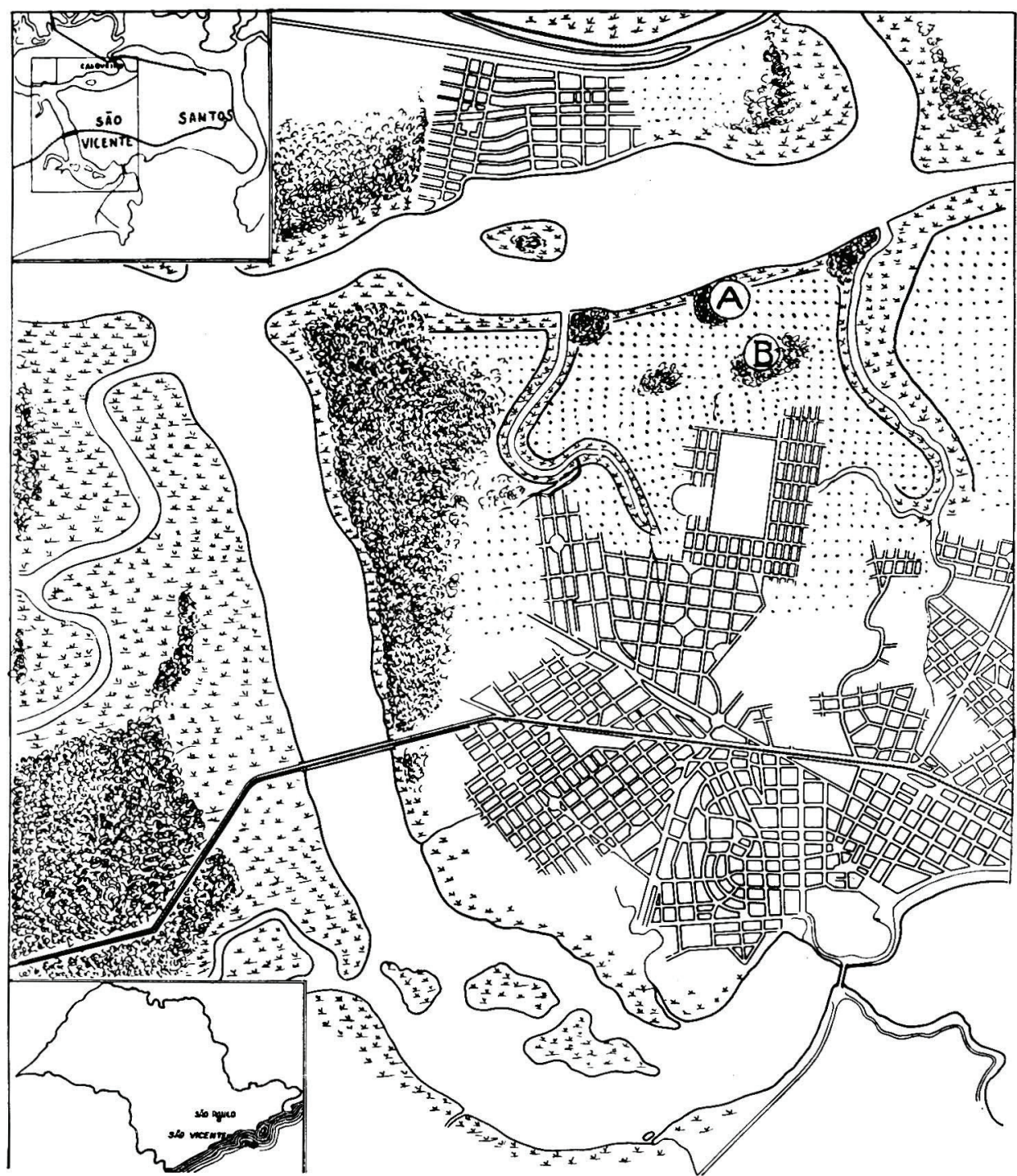

Fíg. 1 - Mapa da região estudada, mostrando sua localização e distribuição dos torrenos.

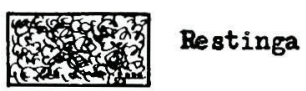

27 waseso
(A) Armadilha com isca animal

(D) Armadilha luminosa

$\because:::::$ Terrenos artificialmente sêcos. 


\section{A REGIAO ESTUDADA}

\section{Localização}

A cidade de São Vicente é sede do Município do mesmo nome, no Estado de São Paulo, Brasil. Está situada em ilha rodeada por canais, na costa atlântica, a $23^{\circ} 58^{\prime}$ de latitude sul e $46^{\circ} 23^{\prime}$ de longitude oeste do meridiano de Greenwich e pouco ao sul da cidade de Santos da qual é contígua. O mapa representado na Fig. 1 fornece idéia dessa localização. A área que foi escolhida para nossas observações, compreende os arredores de São Vicente incluindo o bairro do Casqueiro embora êste último pertença a outro Município, o de Cubatão.

\section{Dados geográficos}

A ilha, sôbre a qual está construida a cidade em questão, recebe o nome de Ilha de São Vicente. Ela está separada do Continente por canais apreciàvelmente largos, aos quais vêm ter rios e cursos de água menores. Forma-se dessa maneira, um sistema complicado de ilhas e canais, diretamente sujeitos à ação das marés, estendendo-se até a raiz da Serra do Mar que constitue o limite ocidental do litoral paulista, nessa região. Unindo a ilha ao Continente, encontram-se quatro pontes, duas para vias férreas e duas para estradas de rodagem. A água dos canais mencionados, pode ser considerada como água do mar, pois seu teor em cloretos pouco difere do dêste último (Figs. 2, 3 e 4).

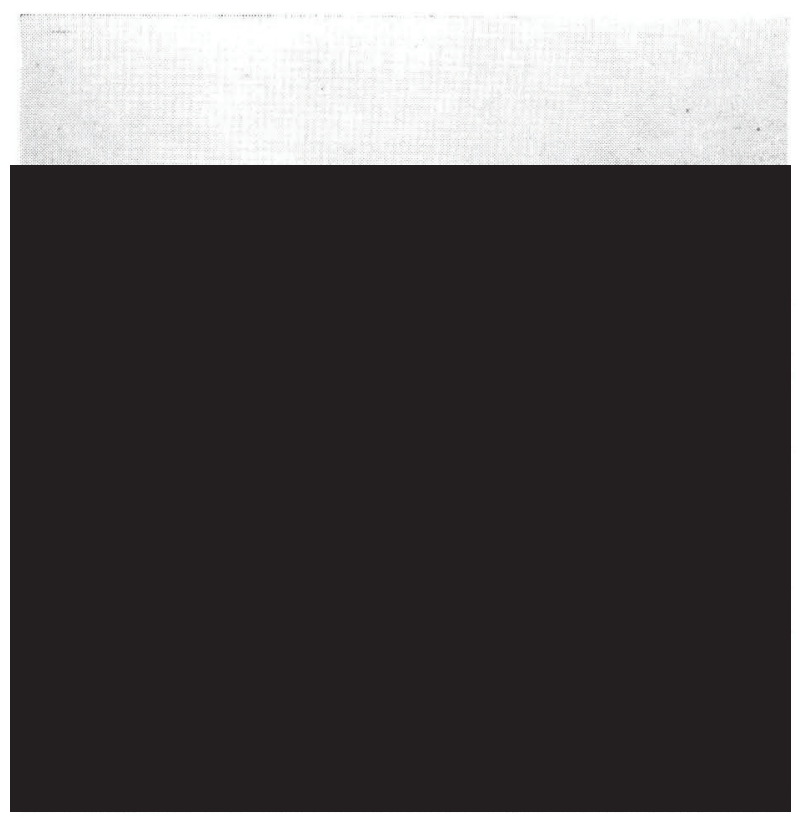

Fig. 2 


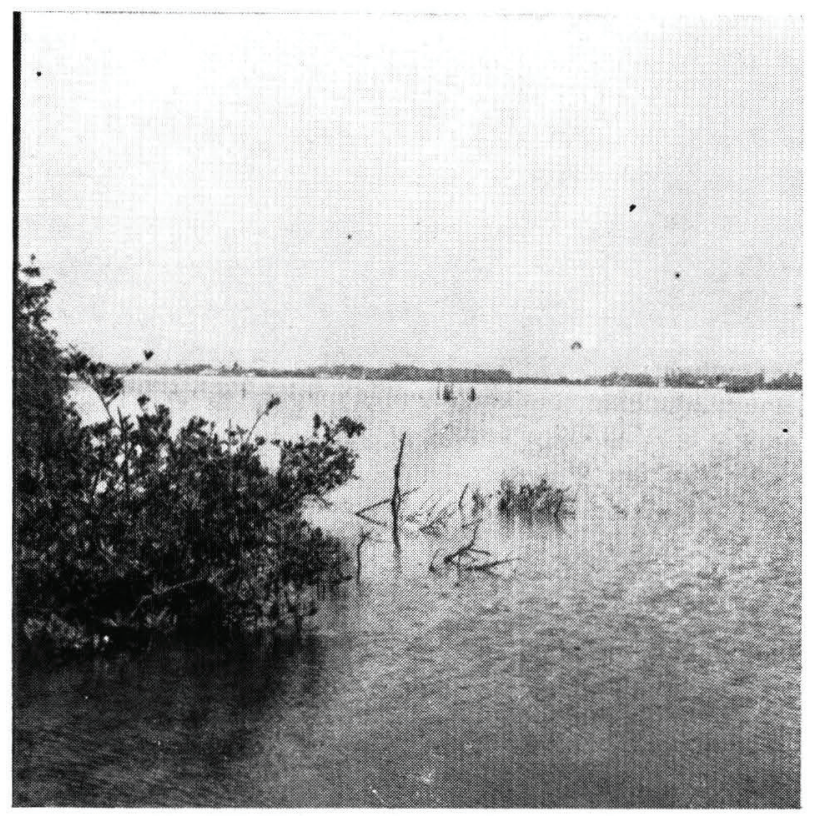

Fig. 3

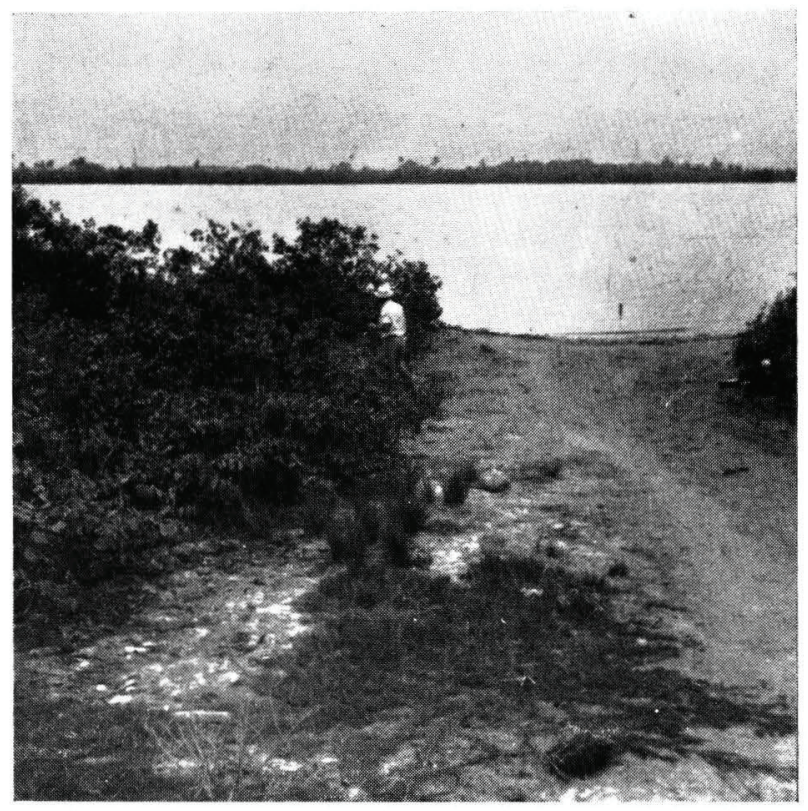

Fig. 4

Aspectos dos canais que rodeiam a Ilha de São Vicente. No segundo plano da Fig. 3 pode-se observar as casas do bairro do Casqueiro ( $M$. Cubatão). Notar a presença da Rhizophora mangle como a espécie dominante do terreno pantanoso marginal ("mangue"). 


\section{Terreno e vegetação}

A região compreende áreas planas e acidentadas. Estas últimas, constituidas por elevações denominadas morros, apresentam-se cobertas de vegetação arbórea. As outras, nas quais levamos a cabo nossas observações, podemos dividí-las em dois grupos: as áreas pantanosas e as áreas sêcas.

Os terrenos pantanosos são representados pelos "mangues" ou pântanos de água salgada. A vegetação dêsses locais é formada quase que exclusivamente pela Rhizophora mangle (Figs. 5, 6, 7 e 8) cuja folha é utilizada na indústria de cortumes. Êsses pântanos são muito ricos em matéria orgânica em decomposição, o que pode ser fàcilmente evidenciado pelo odor pronunciado de gás sulfídrico que dêles emana. Ocupam grandes extensões, distribuindo-se principalmente pelas margens dos canais e mesmo no interior. Êles estão diretamente sujeitos à ação das marés, permanecendo inundados quando a maré sobe e podendo ser percorridos a pé quando a maré desce, como mostram as Figuras 7 e 8.

As área sêcas, acreditamos poder identificá-las como sendo a chamada restinga de Veloso, Moura e Klein ${ }^{37}$ (1956). Nessas áreas, o terreno é mais elevado e não sofre a influência das marés. A vegetação é predominantemente arbustiva e bastante uniforme, havendo contudo, freqüente invasão de espécies arbóreas próprias das áreas acidentadas ou tipo climax (Veloso, Moura e Klein ${ }^{37}$ 1956). As Figuras 9, 10 e 11 dão idéia dêsse aspecto.

Devemos assinalar que, nestes últimos anos, graças à abertura de largos canais e formação de aterros, grandes áreas de "mangue" situadas ao redor de São Vicente, secaram. Como consequiência, formaram-se terrenos planos e sêcos, não mais sujeitos à ação das marés, onde primitivamente dominava o pantanal. Em vista disso, ao lado da Rhizophora mangle, desenvolveu-se variada vegetação rasteira (Figs. 12, 13, 14 e 15). Tais terrenos foram em seguida, submetidos ao processo de loteamento, com abertura de ruas, percorridas em tôda sua extensão por vales de drenagem, como veremos mais adiante.

As Figuras 1 e 16 trazem, respectivamente, um mapa e um desenho diagramático da região. Está assinalada a distribuição dos três grupos de terrenos e vegetação acima descritos: "mangue", restinga e terrenos sêcos artificialmente. 


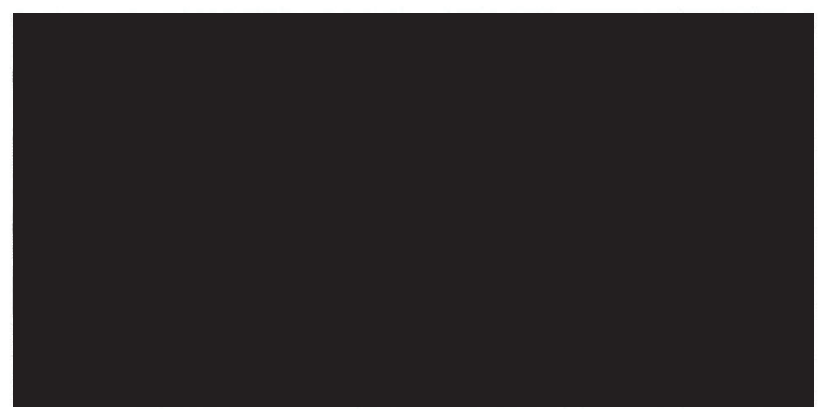

Fig. 5

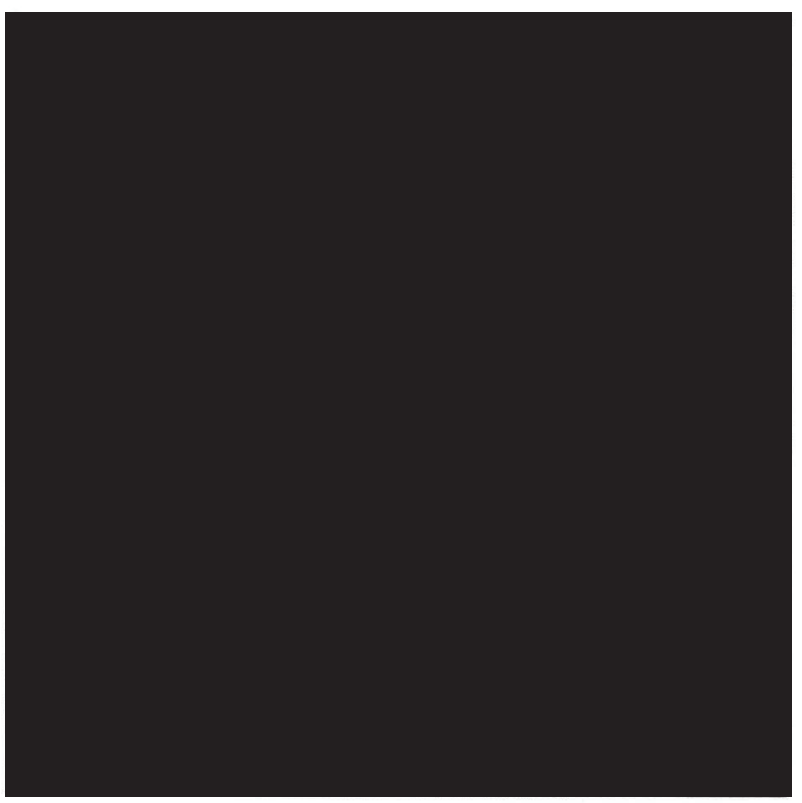

Fig. 6 


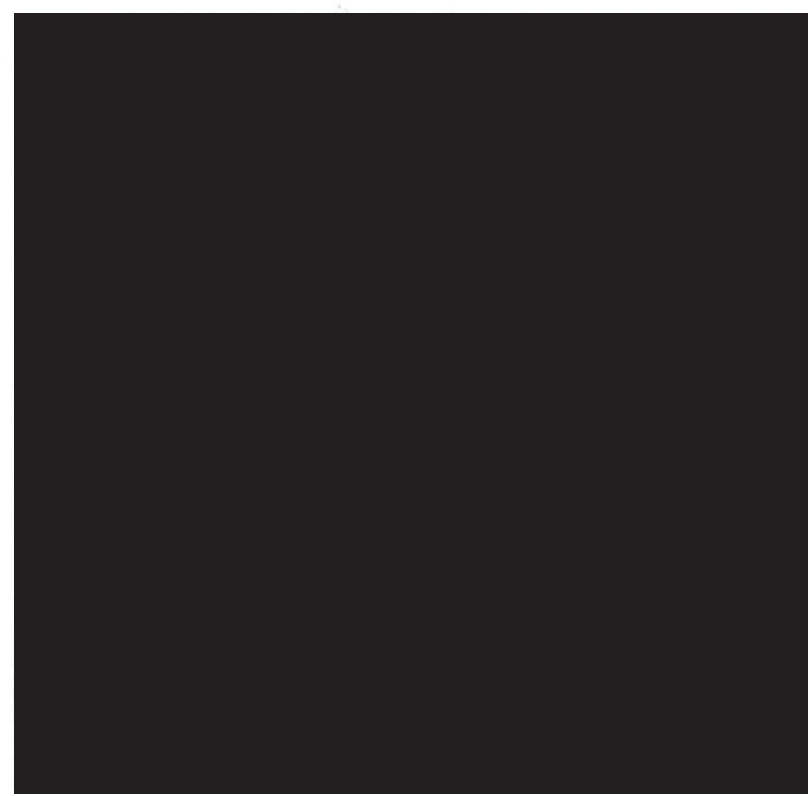

Fig. 7

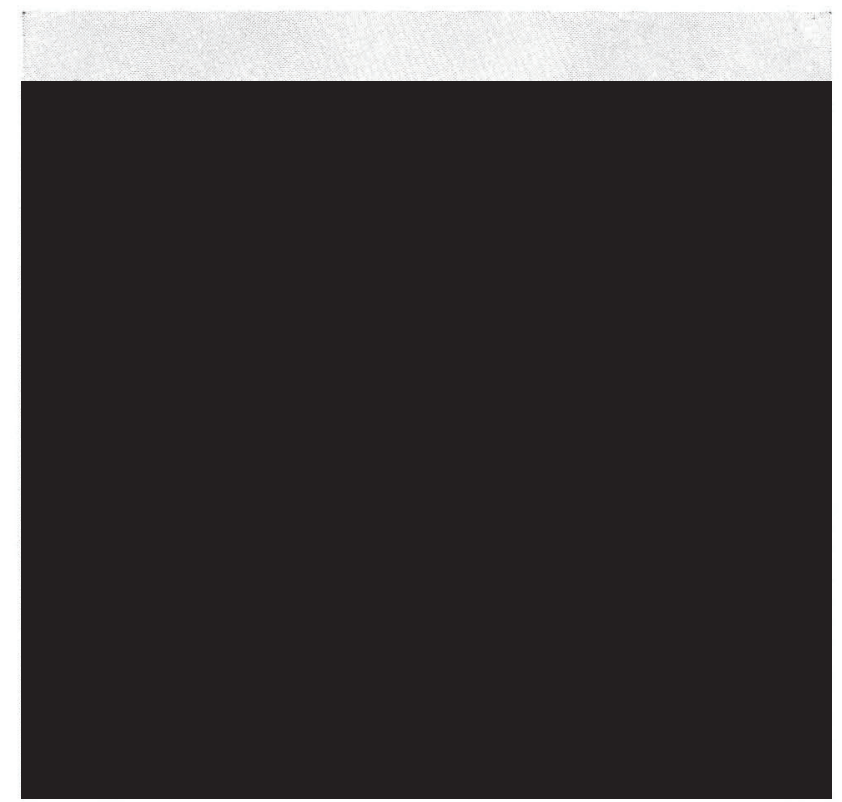

Fig. 8

Aspectos dos terrenos pantanosos ou "mangues", onde predomina quase totalmente a espécie Rhizophora mangle.Fig. 5-Visão panorâmica de uma área atravessada pela Estrada de Ferro Sorocabana; Fig. 6 - Trecho de "mangue" na margem de um canal, notando-se em segundo plano, o bairro do Casqueiro; Fig. 7 - Aspecto do terreno sendo atingiuo pela alta maré; Fig. 8 - O mesmo, na baixa maré, permitindo a passagem sem contacto com a água salgada. 


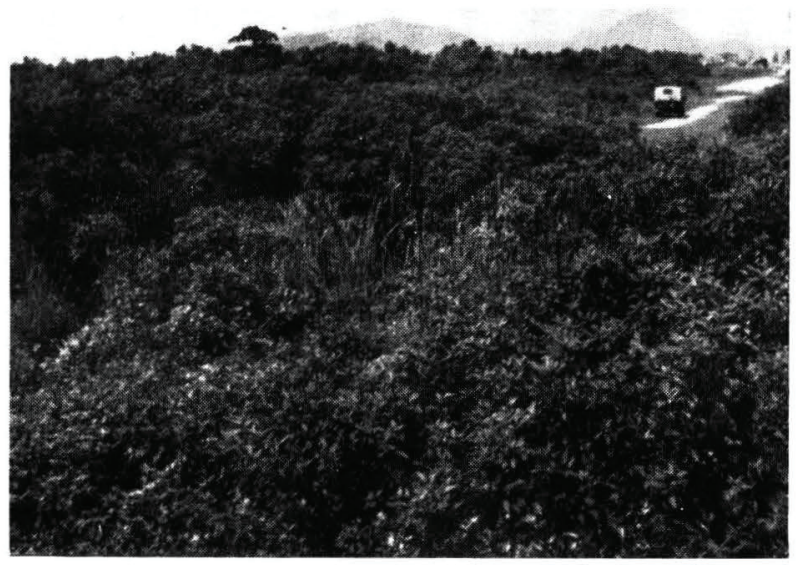

Fig. 9

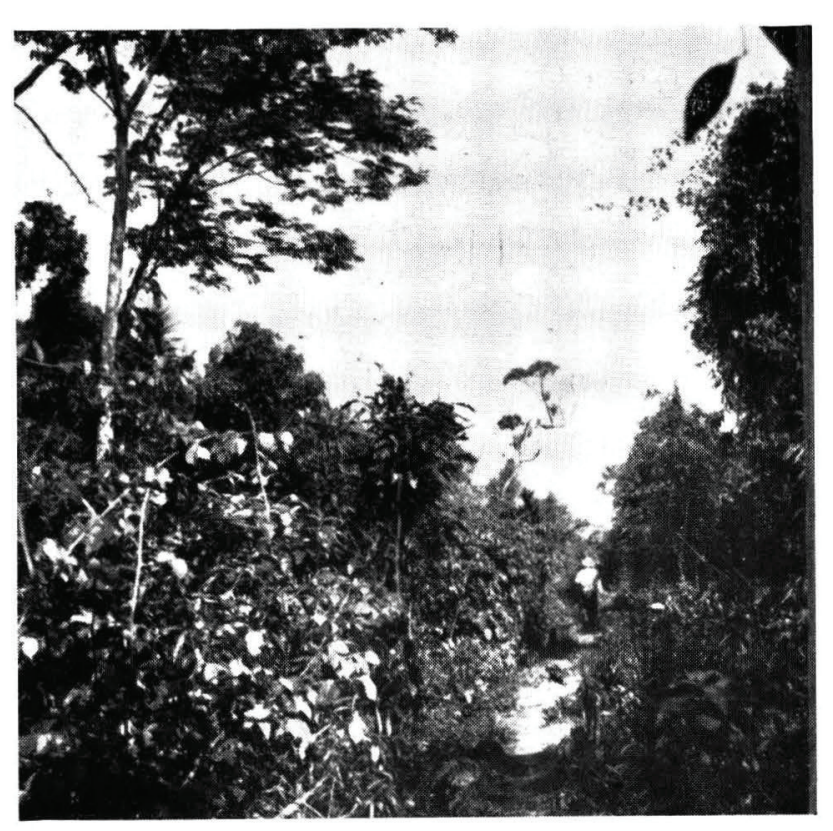

Fig. 10 


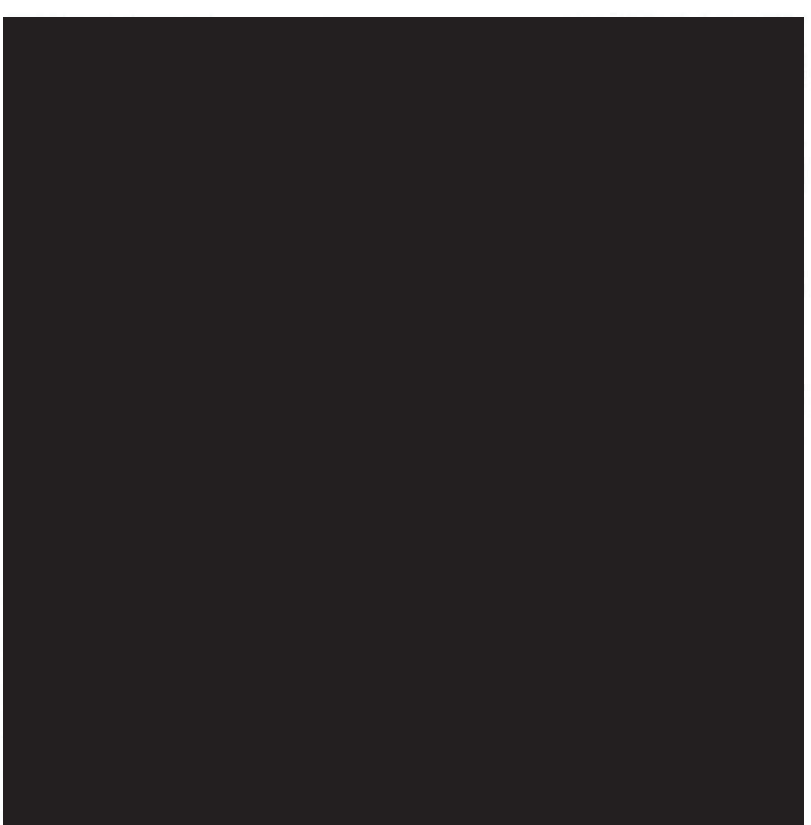

Fig. 11

Aspectos da restinga, com vegetação predominantemente arbustiva. Fig 9 - Vista panorâmica dêsse tipo de terreno, notando-se em segundo plano e à direita, algumas casas da cidade de São Vicente; Figs. 10 e 11 - Aspecto interno da restinga, notando-se o tipo de vegetação regularmente uniforme com predominância de arbustos, embora haja freqüente invasão de espécies arbóreas características dos terrenos acidentados.

\section{Caracteres sociais}

Embora a existência de São Vicente date de longa data, a povoação de seus arredores e conseqüentemente, a formação de novos núcleos residenciais, é fenômeno relativamente recente. Já tivemos ocasião de mencionar a recuperação de terrenos pantanosos e subseqüente loteamento, com a abertura de ruas percorridas em tôda a extensão, por valas de drenagem, como mostra a Figura 18. Nessas áreas assim loteadas vem-se processando povoamento regularmente intenso, que se traduz pela construção de casas. Tais habitações porém, nem sempre são de padrão satisfatório, e o mais freqüente é encontrar construções modestas, de madeira ou mesmo de tijolos, a mais das vêzes em precário estado de conservação. Convém acrescentar que, em virtude da ausência de rêde de esgotos, os resíduos humanos e as águas servidas, via de regra são canalizadas para as valas das ruas. Tal fato chama tanto mais a atenção, quanto maior fôr o número de construções existentes, como é o caso do bairro do Casqueiro (Figs. 17, 18, 19 e 20). 


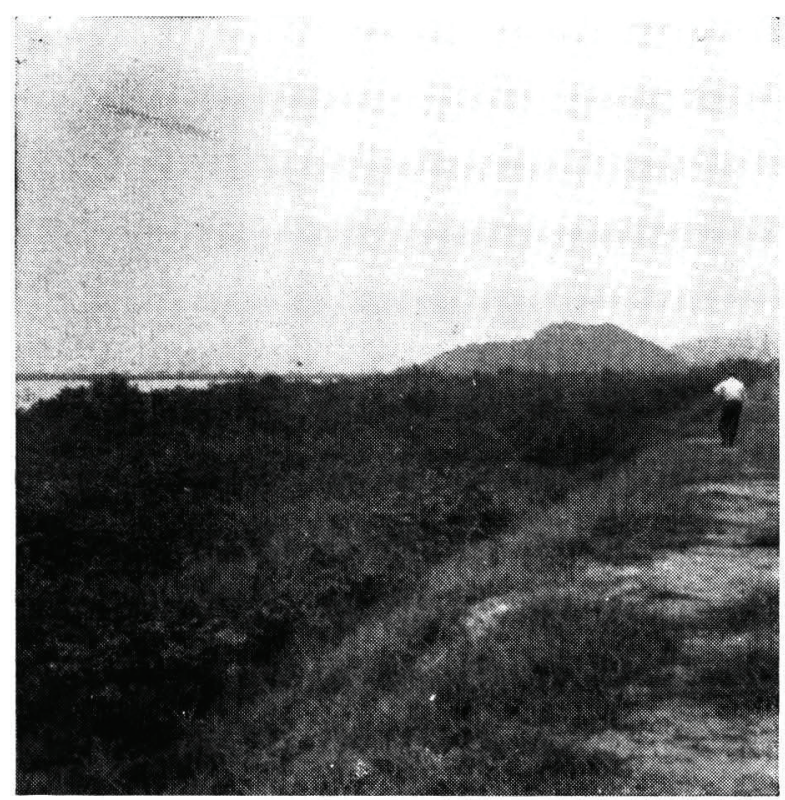

Fig. 12

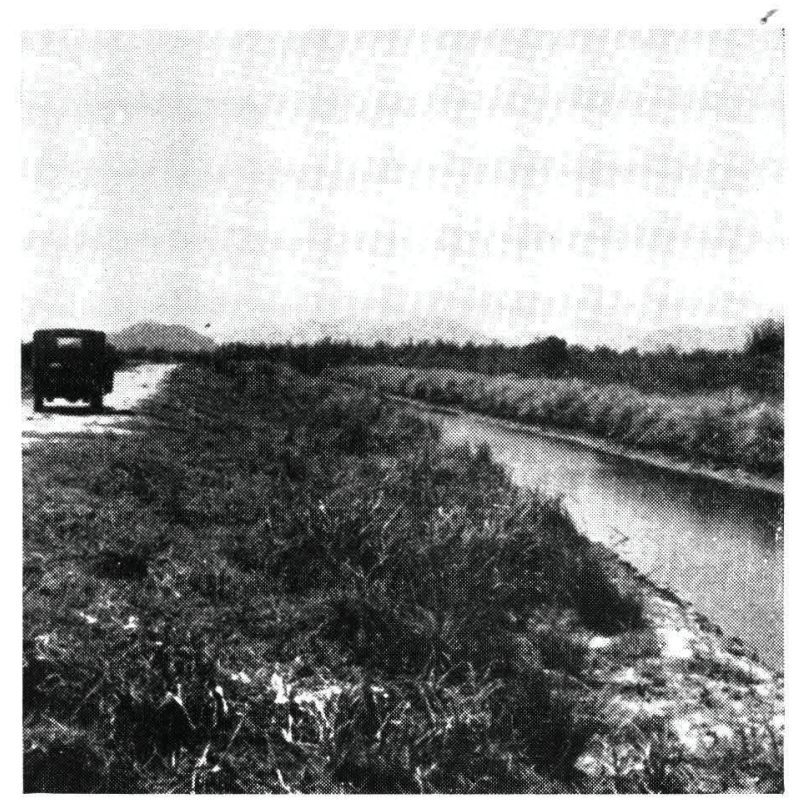

Fig. 13

Aterros e canais destinados à secagem dos terrenos pantanosos. Fig. 12 - Vista de trecho de aterro, notando-se à esquerda, porção remanescente do "mangue"; Fig. 13 - Aspecto de um aterro e canal. 


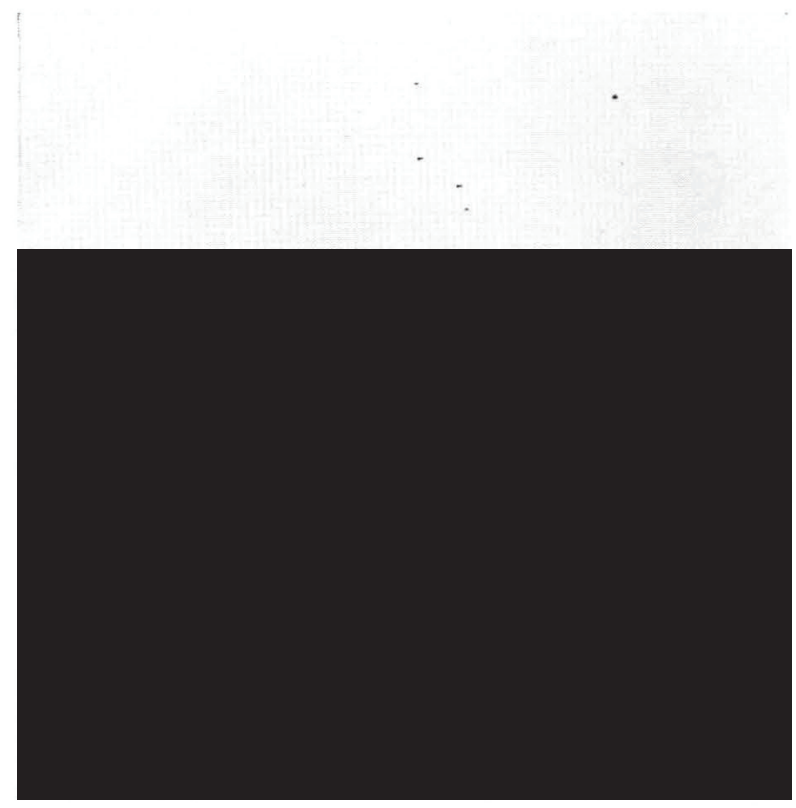

Fig. 14

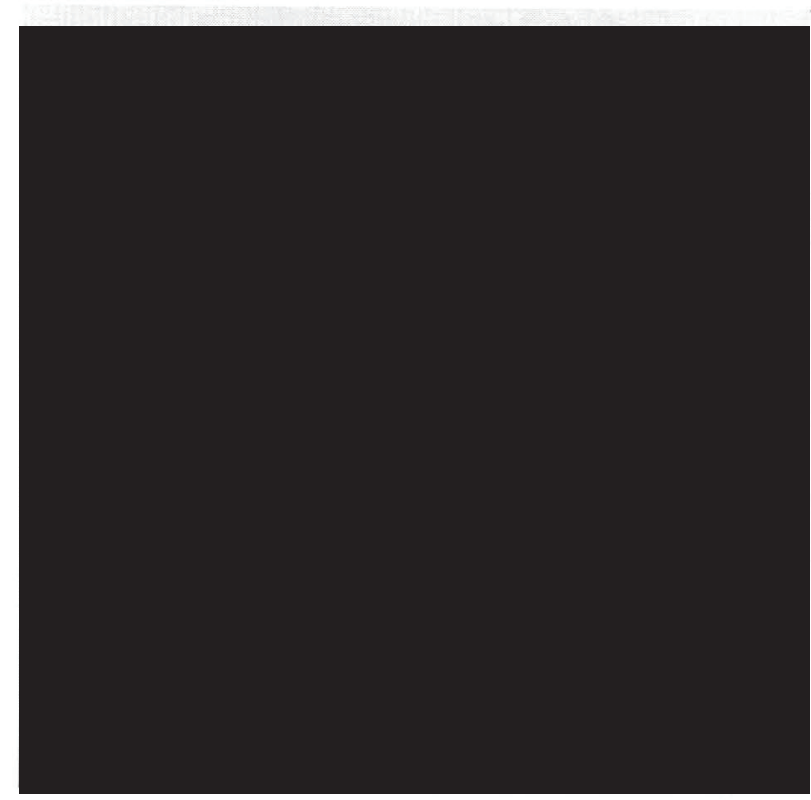

Fig. 15

Aspectos dos terrenos resultantes da secagem dos "mangues". Fig. 14 - Vista panorâmica, notando-se, em segundo plano e à direita, um trecho de restinga; Fig. 15 - Aspecto de que se reveste a vegetação dos antigos terrenos pantanosos, agora não mais sujeitos à ação das marés e portanto, sem contacto com a água salgada. Notar a presença de espécies rasteiras, além da Rhizophora mangle. 


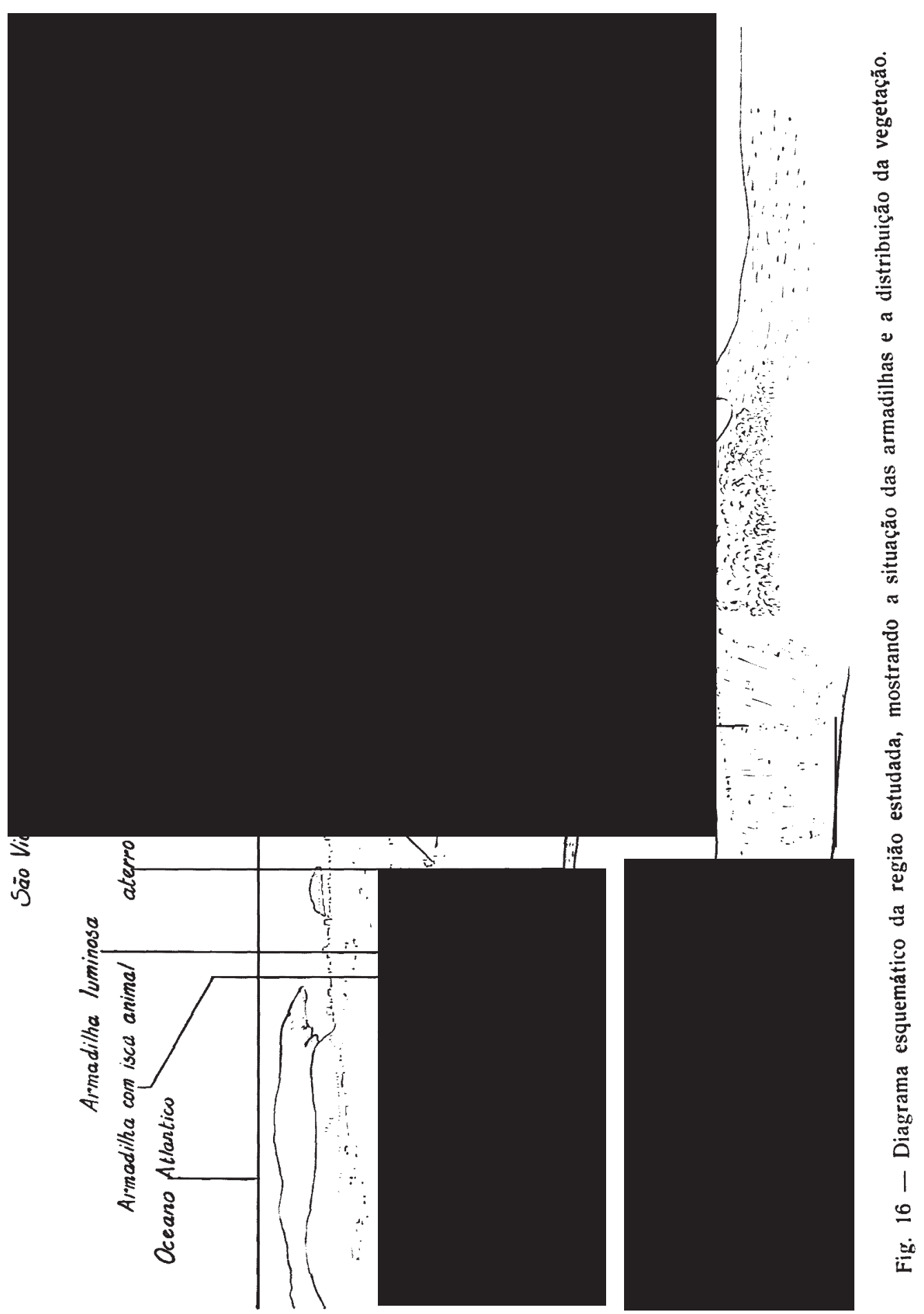




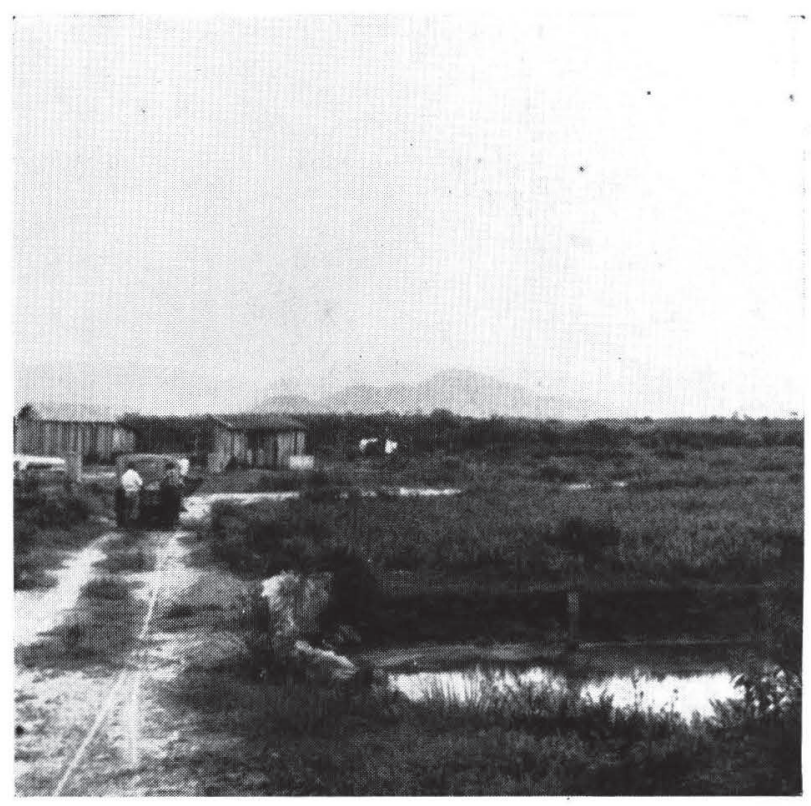

Fig. 17

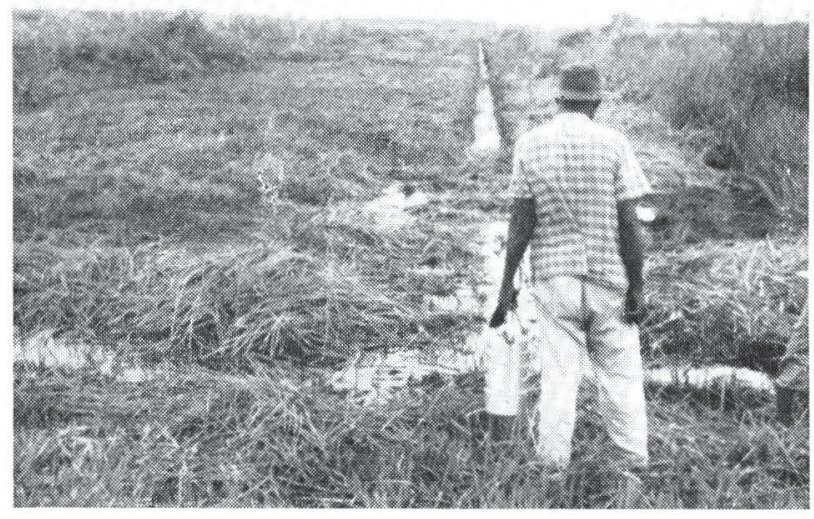

Fig. 18 


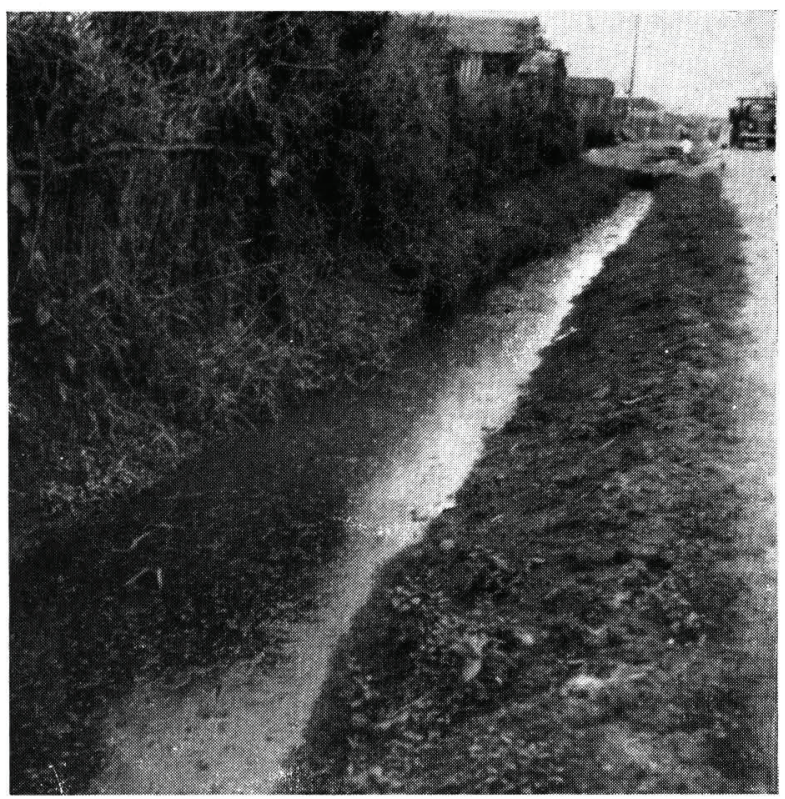

Fig. 19

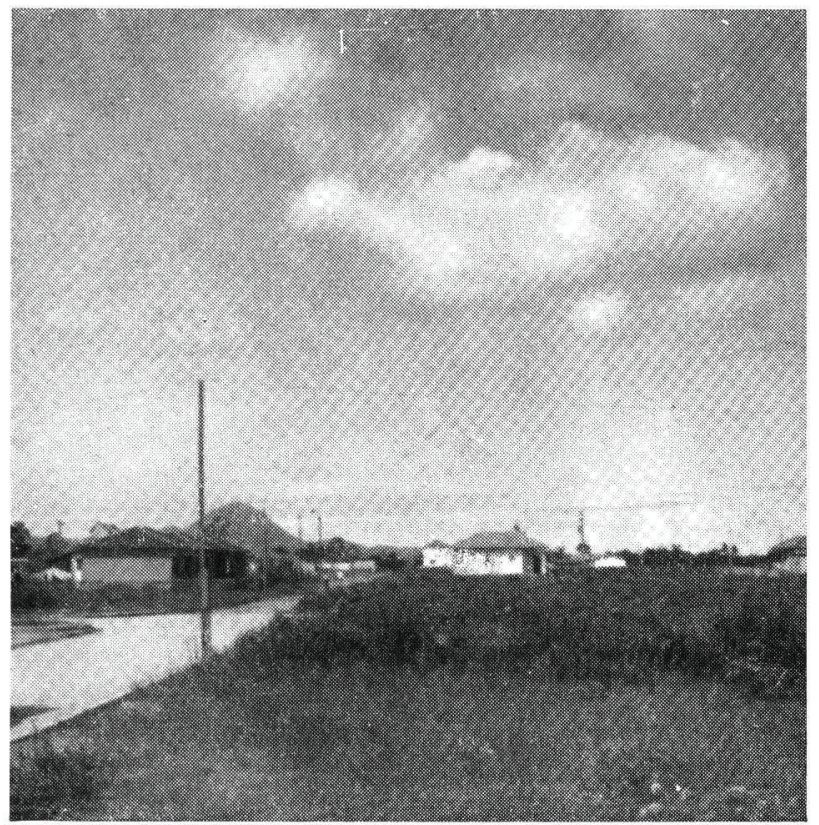

Fig. 20

Arredores de São Vicente. Fig. 17 - Vista dos terrenos loteados, com início de construção de casas; Fig. 18 - Aspecto de rua recém-aberta, notando-se as valas de drenagem ao longo de todo seu comprimento; Fig. 19 - Vala de rua no bairro do Casqueiro, que serve para despejo de esgotos e água servida; Fig. 20 - Aspecto de casas recentes e bairro em formação. 
A população local, na sua grande maioria, trabalha na própria cidade ou em Santos. Fazem exceção algumas atividades extrativas locais, como a pesca e a colheita de folhas de Rhizophora.

TABELA 1 - Elementos meteorológicos observados no periodo de agôsto de 1955 a julho de 1957 no Pôsto de Santos, Estado de São Paulo, Brasil (2356' de latitude sul e $46^{\circ} 20^{\prime}$ de longitude oeste de Greenwich) *

\begin{tabular}{|c|c|c|c|c|c|c|c|}
\hline \multirow[b]{2}{*}{ Anos e meses } & \multicolumn{5}{|c|}{ Temperatura } & \multicolumn{2}{|c|}{ Chuva } \\
\hline & $\begin{array}{l}\text { de Ar } \\
\text { (média) }\end{array}$ & $\begin{array}{l}\text { Máxima } \\
\text { (média) }\end{array}$ & $\begin{array}{l}\text { Mínima } \\
\text { (média) }\end{array}$ & $\begin{array}{c}\text { Máxima } \\
\text { absoluta }\end{array}$ & $\begin{array}{l}\text { Mínima } \\
\text { absoluta }\end{array}$ & $\begin{array}{c}\text { Total } \\
\text { em } \\
\text { mms. }\end{array}$ & $\begin{array}{c}\text { Carga } \\
\text { máxima } \\
24 \text { horas }\end{array}$ \\
\hline \multicolumn{8}{|l|}{1955} \\
\hline Agôsto ........ & 18.0 & 21.8 & 14.8 & 30.4 & 4.3 & 142.1 & 49.4 \\
\hline Setembro ..... & 19.5 & 23.3 & 16.7 & 35.8 & 11.3 & 53.9 & 26.0 \\
\hline Outubro ...... & 19.9 & 22.4 & 17.5 & 28.3 & 13.2 & 62.7 & 22.8 \\
\hline Novembro . & 21.0 & 23.7 & 18.1 & 27.0 & 15.2 & 125.0 & 37.6 \\
\hline Dezembro & 23.9 & 26.6 & 21.2 & 32.8 & 18.1 & 175.2 & 33.2 \\
\hline \multicolumn{8}{|l|}{1956} \\
\hline Janeiro . & 26.7 & 23.5 & 20.0 & 37.6 & 21.4 & 178.7 & 76.8 \\
\hline Fevereiro & 25.3 & 28.8 & 22.2 & 33.0 & 19.1 & 312.9 & 97.8 \\
\hline Março .. & 24.0 & 27.5 & 21.2 & 32.8 & 19.5 & 954.6 & 175.3 \\
\hline Abril ... & 22.5 & 25.9 & 19.8 & 34.8 & 16.1 & 325.8 & 81.8 \\
\hline Maio & 19.0 & 21.8 & 16.7 & 27.0 & 13.4 & 259.0 & 65.2 \\
\hline Junho .. & 17.8 & 20.6 & 15.4 & 25.2 & 12.3 & 230.8 & 75.6 \\
\hline Julho $\ldots \ldots \ldots$ & 17.4 & 21.1 & 14.7 & 29.2 & 10.3 & 207.1 & 152.6 \\
\hline Agôsto $\ldots .$. & 17.3 & 21.0 & 13.9 & 26.7 & 10.6 & 185.8 & 73.6 \\
\hline Setembro $\ldots$ & 20.5 & 24.4 & 17.8 & 38.1 & 13.3 & 128.4 & 22.8 \\
\hline Outubro $\ldots$ & 20.4 & 22.9 & 18.2 & 27.4 & 15.7 & 183.4 & 78.8 \\
\hline Novembro ..... & 20.8 & 23.1 & 18.2 & 26.7 & 14.9 & 155.2 & 84.9 \\
\hline Dezembro ..... & 22.7 & 25.1 & 19.7 & 32.3 & 16.0 & 150.6 & 76.0 \\
\hline \multicolumn{8}{|l|}{1957} \\
\hline Janeiro ..... & 24.6 & 27.7 & 21.6 & 36.6 & 19.2 & 281.5 & 85.0 \\
\hline Fevereiro $\ldots$ & 24.6 & 28.2 & 21.8 & 33.3 & 18.3 & 423.3 & 129.6 \\
\hline Março .... & 24.4 & 27.4 & 21.8 & 31.0 & 19.7 & 258.4 & 45.5 \\
\hline Abril . & 22.6 & 25.8 & 19.8 & 28.4 & 17.0 & 208.9 & 39.2 \\
\hline Maio $\ldots \ldots \ldots$ & 20.0 & 23.3 & 16.9 & 30.3 & 12.2 & 31.4 & 16.8 \\
\hline Junho $\ldots \ldots \ldots$ & 18.2 & 23.0 & 15.2 & 30.4 & 9.8 & 50.7 & 24.6 \\
\hline Julho $\ldots \ldots \ldots$ & 18.2 & 22.2 & 15.1 & 34.6 & 11.3 & 171.4 & 52.2 \\
\hline
\end{tabular}

* Dados fornecidos pelo Instituto Regional de Meteorologia do Ministério da Agricultura - Sāo Paulo, Brasil.

\section{Clima}

O litoral do Estado de São Paulo, onde se situa a região em questão, compreende segundo a classificação climática de Koeppen (in Setzer ${ }^{33}$ 1943-5), área de clima tropical úmido sem estiagem. Segundo Setzer ${ }^{33}$ (1943-5), sendo os solos de baixa capacidade de retenção dágua e mal 
revestidos pela vegetação, favorecem o aquecimento do ar. Dessa maneira, alargam-se as áreas cuja temperatura média do mês menos quente atinge $18^{\circ} \mathrm{C}$, que é o característico do clíma tropical.

A Tabela 1 resume os elementos meteorológicos observados no período que vai de agôsto de 1955 a julho de 1957, no Pôsto Aéreo-Climatológico de Santos, segundo dados fornecidos pelo Instituto Regional de Meteorologia do Ministério da Agricultura em São Paulo.

\section{MÉTODOS UTILIZADOS}

A coleta do material que serviu ao presente trabalho foi executada adotando técnicas preconizadas por vários autores. Foram as seguintes, considerando em separado as para formas imaturas e as para adultos.

\section{Coleta de formas imaturas}

Os processos destinados a evidenciar a presença de larvas e pupas, podem ser resumidos da seguinte maneira:

a) pesquisa microscópica direta;

b) caixas de recuperação;

c) flutuação.

O primeiro dêsses métodos consiste simplesmente em examinar ao microscópio o material colhido, com o objetivo de surpreender as formas imaturas. É muito trabalhoso e sòmente aplicável em casos de investigação restritos a pequenas áreas. Painter ${ }^{31}$ (1926) usou-o em seus trabalhos.

O segundo, foi preconizado por Dove, Hall e Hull ${ }^{6}$ (1932) descrevendo dispositivos que êles denominaram de caixas de recuperação ("recovery cages"). Consiste no emprêgo de caixotes de madeira, abertos de um lado e cobertos de tela ou pano (etamine) de côr preta, no fundo. Lateralmente possuem abertura circular onde se encaixa a bôca de um jarro de vidro. Tais caixas são colocadas sôbre o terreno a pesquisar e os adultos que emergem das formas imaturas alí existentes, devido à atração da luz vão se acumular no recipiente de vidro. O princípio em que se baseia êste processo, já tinha servido a Lutz ${ }^{26}$ (1912) para a pesquisa em buracos de carangueijos e outros locais. O uso dessas caixas ou de outros dispositivos baseados no mesmo princípio, foi adotado por Woke ${ }^{42}$ (1954), Williams ${ }^{39}$ (1955) e Murray ${ }^{29}$ (1957).

O método da flutuação baseia-se no fato de obterem-se com facilidade as larvas e pupas, mediante a suspensão em água do material colhido. Dove, Hall e Hull ${ }^{6}$ (1932), tirando proveito do hábito migratório das larvas, idealizaram um sistema constituido por dois cristalizadores de tamanhos diferentes. 0 menor, contendo o material a ser examinado, é colocado 
dentro do maior. Em seguida, adiciona-se água até submergí-lo completamente. As larvas são colhidas nas margens do cristalizador maior para onde elas migram. Williams ${ }^{38}$ (1951) e Woke ${ }^{42}$ (1954) usaram êste processo. O mesmo princípio foi utilizado por Carpenter ${ }^{3}$ (1951), que realizava uma suspensão em água do material a examinar, deixava em repouso durante a noite, e depois pesquisava as formas imaturas junto às margens do recipiente.

O processo que adotamos em nossas observações foi, em linhas gerais, aquêle de Carpenter ${ }^{3}$ (1951). O material colhido era constituido por lodo e água dos "mangues", valas, poças e buracos de carangueijos. O primeiro era retirado com o auxílio de pequena pá manual, e os locais escolhidos eram as margens e o fundo raso das várias coleções de água. Ao lado disso, colhiam-se amostras de água. A seguir, colocava-se o material em recipientes de alumínio e transportava-se para o laboratório. Para êsse fim, escolhemos as chamadas "marmitas" usadas comumente para o transporte de alimentos. Motivou essa escolha, o fato de apresentarem diversas vantagens como, serem de alumínio e portanto inquebráveis, adaptarem-se umas sôbre as outras e serem assim, levadas fechadas. Como se pode ver, isso possibilitou o transporte fácil do material até São Paulo, onde temos o nosso laboratório. As Figuras 21, 22, 23 e 24 dão idéia do processo da colheita que descrevemos acima, bem como mostram as "marmitas" usadas para o transporte.

Uma vez chegado ao laboratório, o material sofria a suspensão em água de torneira, dentro de bacias esmaltadas. Em seguida, deixava-se em repouso até o dia seguinte. A água era também colocada em idênticos recipientes, e examinada na mesma ocasião. As larvas eram fàcilmente visíveis, graças ao seu movimento serpenteante. Quanto às pupas, embora com pouca mobilidade, eram, prontamente evidenciadas pela morfologia peculiar. Tanto as larvas como as pupas eram logo a seguir, "pescadas" por meio de pipetas e transferidas a pequenos recipientes de vidro ou louça, onde tinham sido prèviamente colocados, água e um pouco de lodo do foco original. Dessa maneira, esperava-se a eclosão dos adultos, o que possibilitava classificação mais rigorosa. Quando as formas imaturas morriam antes de dar origem aos alados, eram guardadas em álcool a $70^{\circ} \mathrm{C}$ e a classificação se fazia posteriormente, por comparação com as outras.

No caso de buracos de carangueijos, fazia-se a verificação prévia da presença de água. Para isso, introduzia-se um tubo de borracha até atingir o líqüido, o que era fàcilmente denunciado ao se obter, assoprando pelo tubo, o barulho característico do borbulhamento. Em seguida, com o auxílio de uma bomba, aspirava-se a água que ia ter a um frasco de vidro. Logo após, com o auxílio de pá ou enxada, procedia-se à excavação e subsequiente colheita do lodo depositado no fundo. No mais, procedia-se como já referimos. As Figuras 25, 26, 27 e 28 dão idéia das diversas fases do processo acima descrito. 


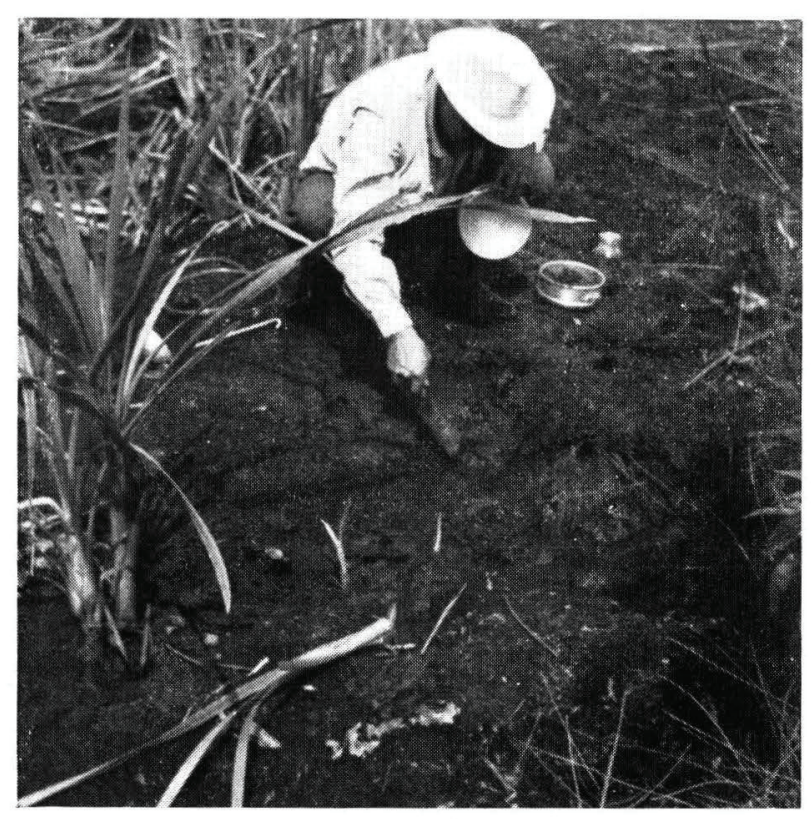

Fig. 21

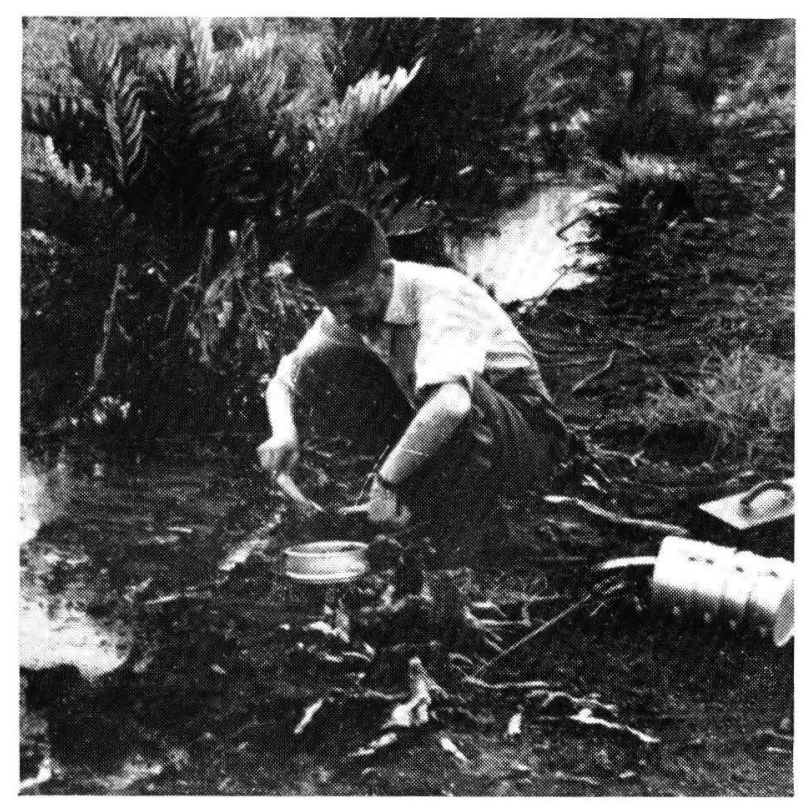

Fig. 22 


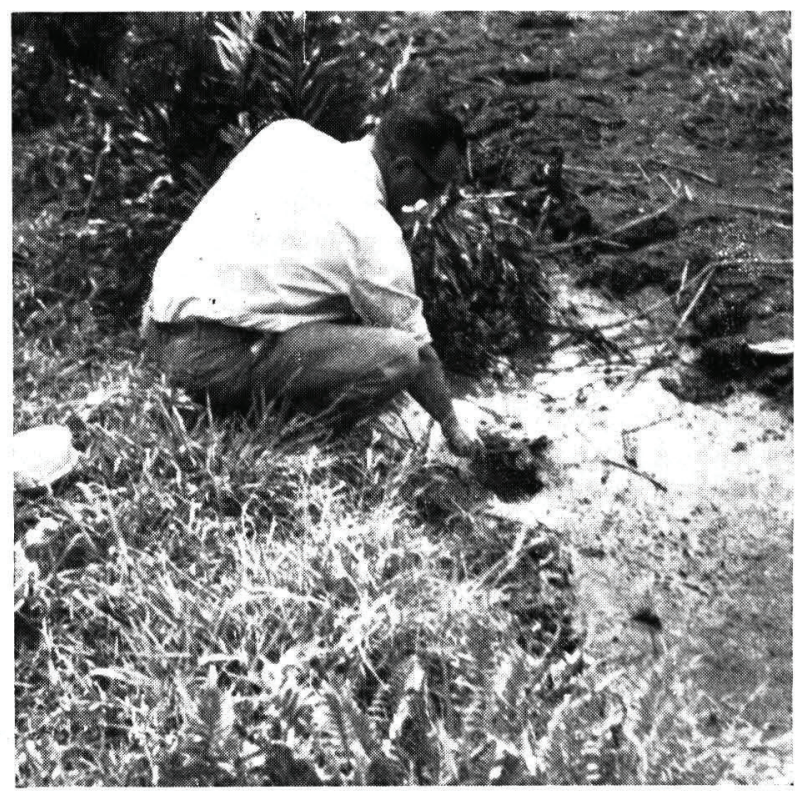

Fig. 23

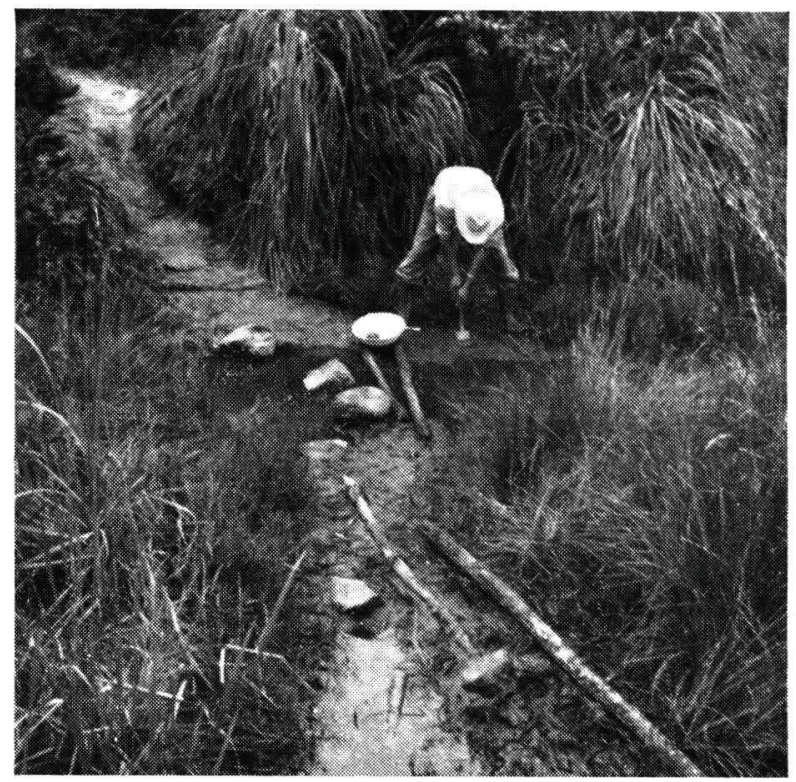

Fig. 24

Colheita de material para pesquisa de formas imaturas de Culicoides. Fig. 21 - Coleta em poça de água; Figs. 22, 23 e 24 - Coletas nas margens de valas. Notar a presença dos recipientes de alumínio ("marmitas") utilizados para o transporte. 


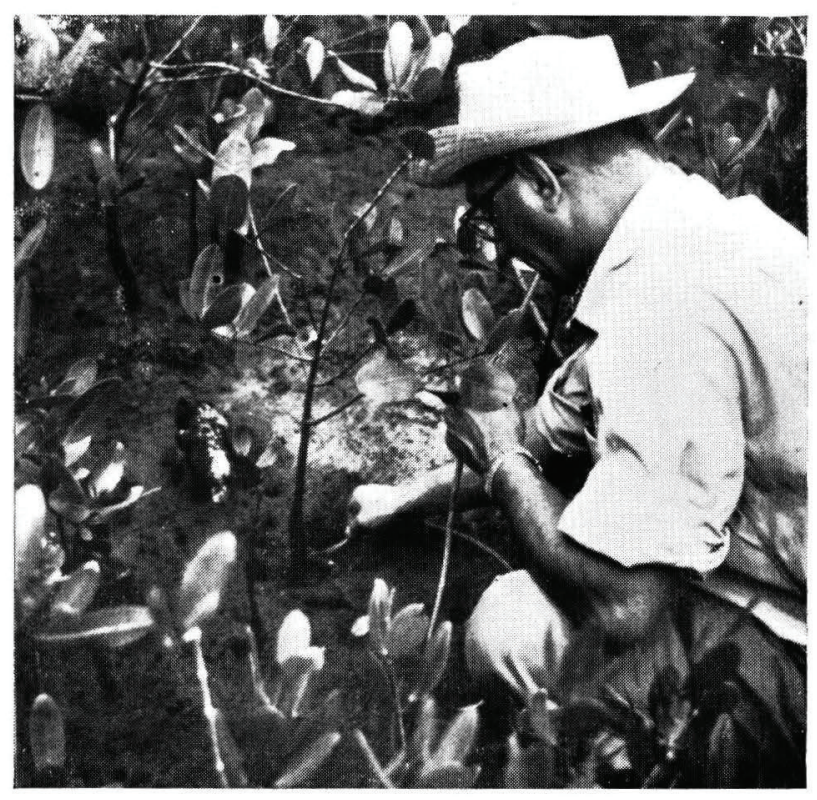

Fig. 25

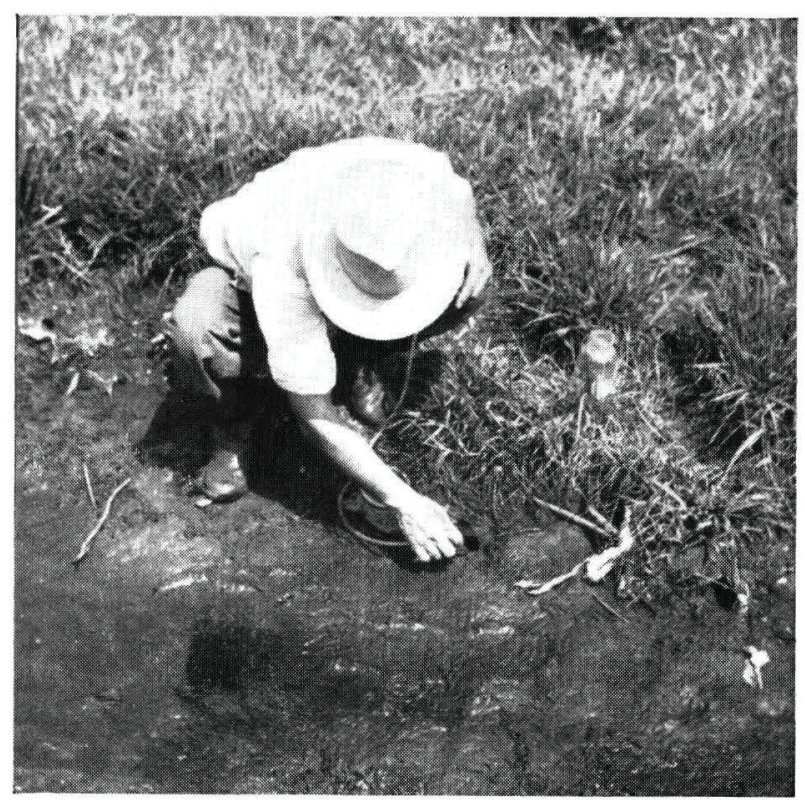

Fig. 26 


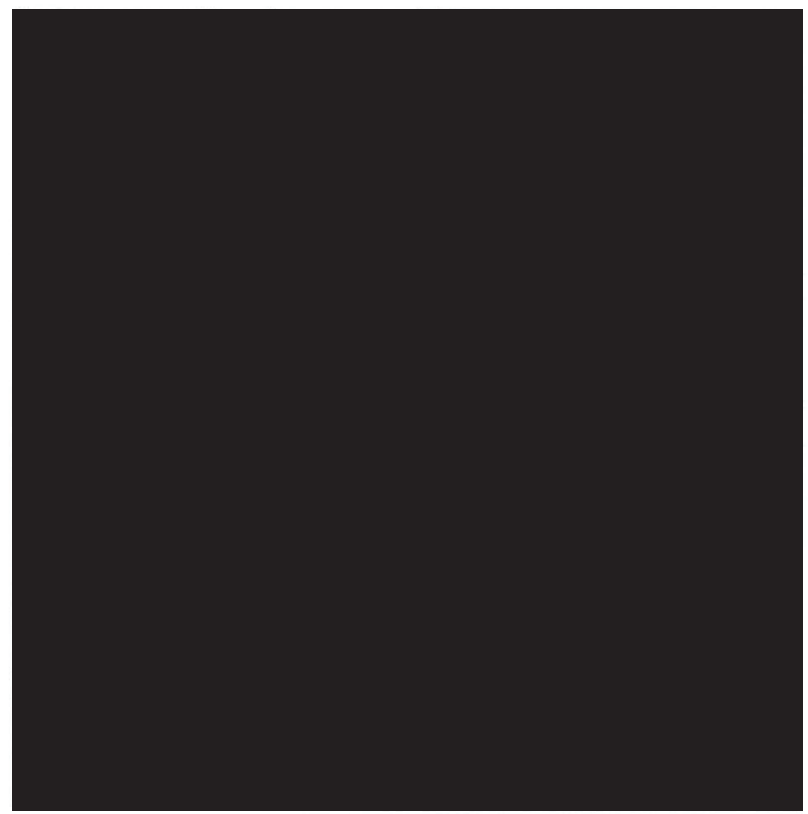

Fig. 27

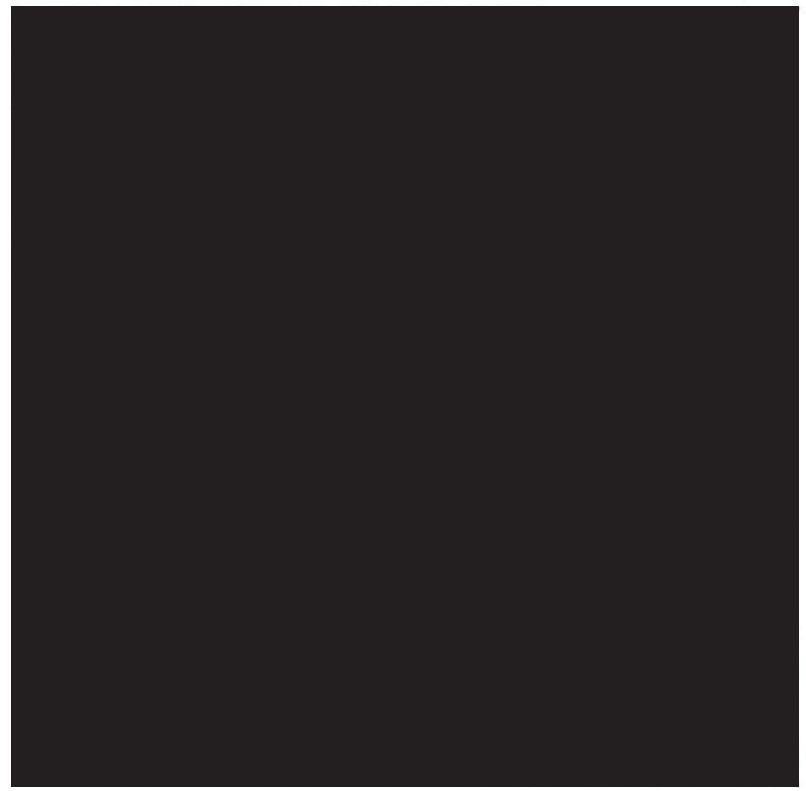

Fig. 28

Colheita de material para pesquisa de formas imaturas de Culicoides, em buracos de carangueijos. Figs. 25 e 26 - Verificação da presença de água, em buracos de Oedipleura cordata L., com a introdução de tubo de borracha; Fig. 27 - Coleta de lôdo no fundo de buraco da mesma espécie; Fig. 28 - Aspiração de água, com o auxílio de bomba, de um buraco de Cardisoma guanhumi L.. 


\section{Captura de adultos}

A coleta dos exemplares alados ten sido objeto de estudo de muitos autores, resultando daí vários processos destinados a alcançar aquêle fim. Embora os "maruins" possam ser capturados dentro das habitaçoes, a sua maior atividade se realiza no meio extra-domiciliar, motivo pelo qual, a maioria das observações foram feitas nesse último ambiente.

Os métodos de captura poden ser enumerados da seguinte maneira:
a) conl o concurso de substâncias adesivas;
b) diretamente sôbre isca humana;
c) conl o concurso de armadilhas;
d) outros métodos.

O primeiro processo consiste simplesmente em lançar mão de substâncias às quais os Culicoides aderem e dai são recolhidos. Carpenter " (1951) adotou-o no Panamá. Êsse autor usava folhas de papel branco, de determinadas dimensões, untadas com óleo e montadas em molduras de madeira. Tais papeis adesivos eram colocados ao redor de um cavalo que servia de isca atraindo os insetos, os quais ficavam aprisionados nas folhas untadas.

A coleta feita diretamente sôbre isca humana tem sido preconizada para o estudo das atividades hematófagas dos "mosquitos pólvora". Snow ${ }^{\text {:4 }}$ (1955) e Williams ": (1955) utilizaram êsse tipo de captura na Região Neártica. Na África, Nicholas et al. "3n (1953) treinaram individuos locais na captura de Culicoides atraidos pela própria presença. Tais capturadores receberam o nome de "fly-boys", e foram amplamente usados por aquêles autores nas suas observações.

Todavia, o método de coleta mais freqüientemente utilizado é aquêle que se baseia no emprêgo de armadilhas. Já Lutz ${ }^{26}$ (1912) construíra um tipo de armadilha luminosa que funcionava automàticamente, e onde os insetos atraidos iam ter a um recipiente apropriado contendo líciuido conservador. Mais recentemente, e em especial os autores americanos, tem-se ampliado o uso da armadilha luminosa da Estação Agrícola Experimental de New Jersey, a chamada "New Jersey Mosquito Light Trap". Numerosos sãos os investigadores que adotaram as armadilhas luminosas como método de captura de adultos. Podemos citar os trabalhos de Hill ${ }^{19}$ (1947), Khalaf $\cdots, \cdots, \cdots(1952,1957)$, Williams $*$, *1 $(1955,1955$ a), Pickard e Snow 32 (1955), Wirth e Bottimer ${ }^{+1}$ (1956), Murray ${ }^{2:}$ (1957) e Beck' (1958). Quanto à Região Neotropical, além das observações de Lutz *' (1912) no Brasil, mencionadas atrás, fizeram uso de armadilhas luminosas, Fox e Kohler $^{1.5}$ (1950), Kohler e Fox ${ }^{* 4}$ (1951), Fox e Maldonado Capriles ${ }^{15}$ (1953), Fox ${ }^{14}$ (1953) em Puerto Rico, e Mirsa ${ }^{26}$ (1953) na Venezuela.

Os Culicoides adultos podem ser capturados sôbre peças de pano ou mesmo do vestuário. Tal foi o processo usado por Williams ${ }^{\text {:s }}$ (1951) no 
Alaska. As coletas intra-domiciliares também podem ser realizadas, como fizeram Carter, Ingram e Mcfie ${ }^{4}$ (1920) na África, e Lutz ${ }^{26}$ (1912) e Mirsa ${ }^{28}$ (1953) na América do Sul. Recentemente, com o uso de avião, Glick ${ }^{17}$ (1957) coletou adultos de $C$. variipennis até uma altura de 5.000 pés (cêrca de 1.500 metros).

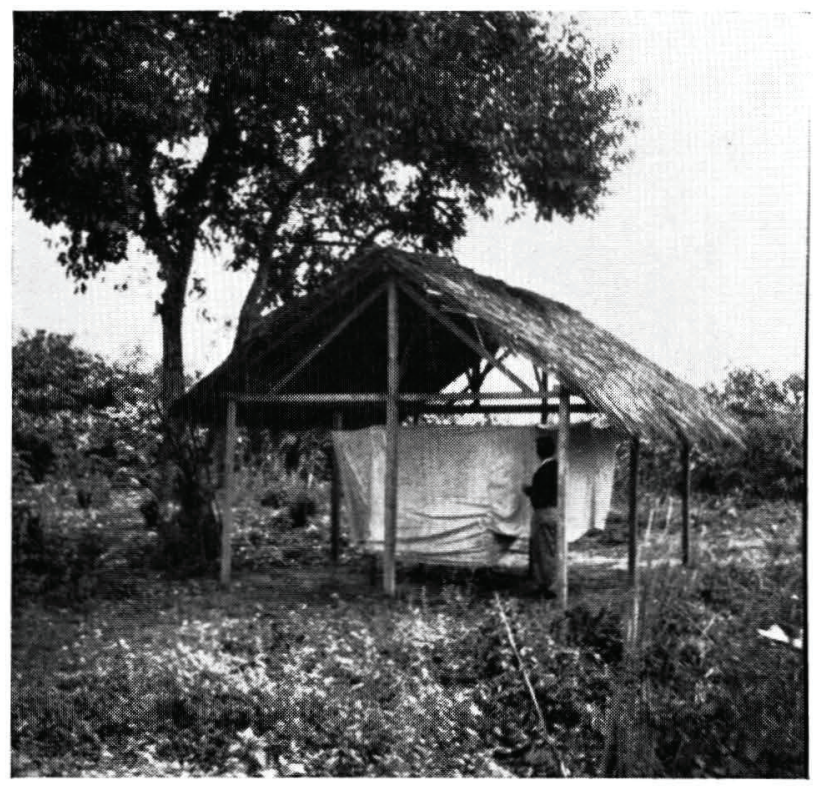

Fig. 29 - Armadilha de Shannon que funcionou com isca animal, de agôsto de 1955 a julho de 1957, em São Vicente.

Nos nossos trabalhos, adotamos a captura em armadilha de Shannon, como a descrevemos em publicação anterior (Forattini $\left.{ }^{8}, 1954\right)$. Utilizamos duas dessas armadilhas, localizadas nos pontos assinalados nas Figuras $1 \mathrm{e}$ 16. Uma delas (Fig. 29), funcionou com isca animal, ininterruptamente, de agôsto de 1955 a julho de 1957. Nela, os Culicoides eram coletados por guardas treinados para êsse fim, e que usavam capturadores constituidos por tubos de vidro com clorofórmio. Tais capturas eram feitas diàriamente, duas vêzes ao dia, obedecendo os seguintes horários: das 6 ás 8 horas e das 17,30 às 20,30 horas. Embora muitos autores tenham preferência pelas coletas levadas a efeito à noite, não existe evidência nítida de periodicidade noturna ou diurna por parte dêsses dipteros. Por essa e outras razões de natureza local, fomos levados a adotar aquêle horário que abranje as primeiras horas do dia e da noite. A segunda armadilha funcionou com isca luminosa representada por um lampeão à querozene "Coleman" de 300 velas, de março a novembro de 1956, com uma interrupção correspondente ao mês de julho do mesmo ano. Nela, as coletas eram realizadas regularmente, duas vêzes por semana, obedecendo ao horário das 19 às 22 horas. 
Operando da maneira descrita, os resultados foram reduzidos à expressão de médias horárias (diária ou mensal), segundo a fórmula:

na qual:

$$
\mathrm{MH}=\frac{\mathrm{N}}{\mathrm{I} \times \mathrm{H}}
$$

$$
\begin{aligned}
\mathrm{MH} & =\text { média horária. } \\
\mathrm{N} & =\text { número de Culicoides capturados. } \\
\mathrm{I} & =\text { número de indivíduos capturadores. } \\
\mathrm{H} & =\text { número de horas de captura. }
\end{aligned}
$$

Dessa forma, as médias horárias referem-se sempre às mesmas horas de coleta que, assim uniformizadas, se prolongaram pelo espaço de tempo já referido.

\section{OBSERVAÇÕES SÔBRE CRIADOUROS NATURAIS}

Devem-se a Lutz ${ }^{26,27}(1912,1913)$, as primeiras observações, na Região Neotropical, sôbre locais de criação de Culicoides. Trabalhando nos arredores da cidade do Rio de Janeiro, constatou êsse autor, que as larvas eram predominantemente aquáticas. Conseguiu observar formas imaturas de C. maruim, C. insignis, C. pusillus e C. furens $(=C$. maculithorax) no lodo colhido nos "mangues". O mesmo autor verificou ainda a espécie $C$. reticulatus criando-se em buracos de carangueijos (Cardisoma guanhumi) e C. bambusicola desenvolvendo-se na água coletada em internós de bambús. Quanto a esta última espécie, o mesmo fato foi constatado posteriormente por Lane ${ }^{25}$ (1947).

Becquaert ${ }^{2}$ (1924), se bem que não tenha conseguido evidenciar os criadouros de $C$. furens em Puerto Castilha, Honduras, supôs que os mesmos fossem coleções pouco profundas, de água doce ou salobra, contendo matéria orgânica em decomposição de origem vegetal. Painter ${ }^{31}$ (1926), trabalhando na mesma localidade que o autor anterior, conseguiu verificar criadouros de $C$. furens e $C$. phlebotomus. O primeiro foi encontrado nas margens de coleções de água com certo teor salino, o segundo em depressões lodosas próximas do terreno arenoso das praias e constantemente úmidas.

Fox ${ }^{13}$ (1942) poude encontrar formas imaturas de C. borinqueni, em buracos de árvores em Puerto Rico, de $C$. hylas $(=C$. heliconiae $)$ em bromélias de Maracay, Venezuela, e de $C$. arubae em buracos de carangueijos nas Indias Ocidentais Holandesas.

Carpenter $^{3}$ (1951), realizando observações na zona do Canal do Panamá, conseguiu verificar que os principais criadouros de Culicoides restringiam-se às áreas baixas, constantemente saturadas, cobertas de camadas rasas de água ou sujeitas a freqüentes inundações. Woke ${ }^{42}$ (1954), trabalhando na mesma região, chegou a conclusões semelhantes. Obteve, o referido autor, o maior número de larvas, em área completamente exposta 
aos efeitos dos raios solares è sujeita diretamente à ação das marés. Concluiu daí que, o desenvolvimento das larvas de $C$. furens, na região que foi objeto de estudo (Balboa, vizinhanças de Panamá) é favorecido pela influência moderada das marés e pela luz solar.

Em recente nota, Forattini, Rabello e Pattoli ${ }^{11}$ (1957) referem o encontro de criadouros de C. maruim, C. insignis, C. guyanensis e C. reticulatus em São Vicente, Brasil. Pelo que acima foi dito, vemos que são poucas as observações sôbre criadouros naturais dêsses dípteros, na Região Neotropical. O que se conhece, poderá ser resumido da seguinte maneira:

1) Coleções de água doce ou salobra, a céu aberto - C. furens, $C$. guyanensis, C. insignis, C. maruim, C. phlebotomus e C. pusillus.

2) Água coletada em buracos de árvores $-C$. borinqueni.

3) Água coletada em bromélias - C. hylas.

4) Água coletada em buracos de carangueijos $-C$. reticulatus, $C$. arubae.

5) Água coletada em internós de bambús $-C$. bambusicola.

As observações que realizamos nos arredores da cidade de São Vicente, já foram parcialmente noticiadas em publicações anteriores (Forattini, Rabello e Pattoli ${ }^{10}, 1956$, Forattini e Rabello ${ }^{9}$, 1956, Forattini, Rabello e Pattoli ${ }^{11}$, 1957, Forattini, Rabello e Pattoli ${ }^{12}$, 1957). No presente trabalho relataremos com mais minúcias, essas investigações, acrescentando dados que contribuirão para melhor idéia de conjunto.

Dados gerais - Como se pode verificar pelo histórico acima exposto, e referente à Região Neotropical, embora seja pequeno o número de observações, são muito variados os tipos de criadouros encontrados. Com efeito, investigações mais numerosas, realizadas em outras regiões faunísticas, tem revelado a presença de larvas de Culicoides em lodo, areia e detritos diversos coletados em pantanais, lagôas, cursos de água, buracos de árvores ou mesmo limo que cobre raízes e cascas de vegetais (Foote e Pratt ${ }^{7}, 1954$ ). Trabalhando em Charleston, U.S.A., Dove, Hall e Hull ${ }^{6}$ (1932) e Hall, Dove e Prince ${ }^{20}$ (1934), verificaram que as larvas de $C$. furens $(=C$. dovei $)$ apresentavam acentuada tendência a se acumularem nas margens dos pântanos e outras coleções, ao nível da água, sendo relativamente pequeno o número daquelas que se afastavam dessa situação.

As larvas de Culicoides são fàcilmente visíveis, graças ao seu rápido movimento vermiforme, em chicote. Nadam na superfície líqüida, procurando um ponto de apôio para repousar, geralmente constituido por detritos flutuantes ou não. Logo após, afundam-se no lodo subjacente, graças a movimento em parafuso. Quando a água sobrenadante seca, elas costumam emergir do lodo. Continuando o dessecamento e atingindo também o lodo, as larvas aprofundam-se novamente, procurando maior umidade. As pupas 
são pouco móveis, permanecendo nas margens das coleções líqüidas, com o abdomen extendido, apresentando de vez em quando, movimentos lentos.

Segundo Thomsen ${ }^{36}$ (1937), as larvas são carnívoras e, em algumas circunstâncias, canibais. Foote e $\operatorname{Pratt}^{7}$ (1954) não verificaram êsse fato em espécies que se criam em buracos de árvores. Observaram êsses autores que, a alimentação das larvas era formada de vegetais em decomposição, associada com algas, protozoários e outros micro-organismos. Tivemos ocasião de observar o tubo digestivo de larvas de $C$. insignis, cheio de algas e detritos vegetais, o que lhe emprestava coloração esverdeada e arroxeada. Verificamos atividade predatória e canibalismo em C. guyanensis. Conseguimos presenciar o ataque de larvas dessa espécie a outras de Stilobezzia as quais, devido a seus movimentos lentos, tornavam-se presas fáceis. Observamos ainda, o ataque de larvas a pupas da mesma espécie, o que nos obrigou à imediata separação destas últimas a fim de podermos obter as formas adultas. Em $C$. reticulatus verificamos que a alimentação era constituida de matéria orgânica em decomposição, vegetal e animal. Conseguimos alimentar larvas dessa espécie com formas imaturas mortas de Culicíneos, que eram ativamente procuradas e ràpidamente consumidas.

Nas condições do laboratório, as larvas permaneciam nesse estádio durante tempo muito variável. Êsse tempo variou desde alguns dias até cêrca de três meses. Para $C$. guyanensis, a pupação processava-se em cêrca de uma hora. O período pupal variou de dois a quatro dias.

Utilizando o processo que já descrevemos, examinamos 189 amostras de lodo e água, das quais 56 forneceram resultado positivo para formas imaturas de Culicoides. Os locais onde se processou a colheita das referidas amostras, poderão ser classificados da seguinte maneira: "mangue", coleções de água em terrenos secos, e buracos de carangueijos. Passaremos a considerar os resultados obtidos em cada um dêsses tipos de criadouros.

Pesquisas em terreno pantanoso ou "mangue" - Como já tivemos ocasião de descrever, o "mangue" é o terreno pantanoso banhado por água salgada. Encontra-se rodeando o local de nossas investigações, a cidade de São Vicente. O lodo que existe nesse pantanal é muito rico em matéria orgânica em decomposição, o que pode ser fàcilmente verificado graças ao odor característico que dêle emana. Habitam êsse terreno diversas espécies de crustáceos, algumas construtoras de buracos e galerias, às quais nos referiremos com maiores detalhes, mais adiante.

Lutz ${ }^{27}$ (1913), utilizando o processo de cobrir áreas do "mangue", durante a baixa maré, conseguiu obter adultos de C. maruim, C. insignis, C. furens $(=C$. maculithorax $)$ e $C$. pusillus. Acreditamos que para êste tipo de terreno, o processo que nós usamos não deva ser muito eficaz, isto devido aos resultados pobres que obtivemos nesse setor, conseguindo apenas algumas pupas. Supomos que o emprêgo das caixas de recuperação forneceria resultados melhores. Dadas as condições locais porém, não pudemos lançar mão dêsse processo. Seja como fôr, obtivemos formas imaturas 
de $C$. maruim e $C$. insignis. O primeiro foi encontrado no "mangue" que margeia os canais, e o segundo, na mesma situação do anterior e, em duas ocasiões, no lodo que se prende às raízes de Rhizophora (Figs. 30 e 31 ).

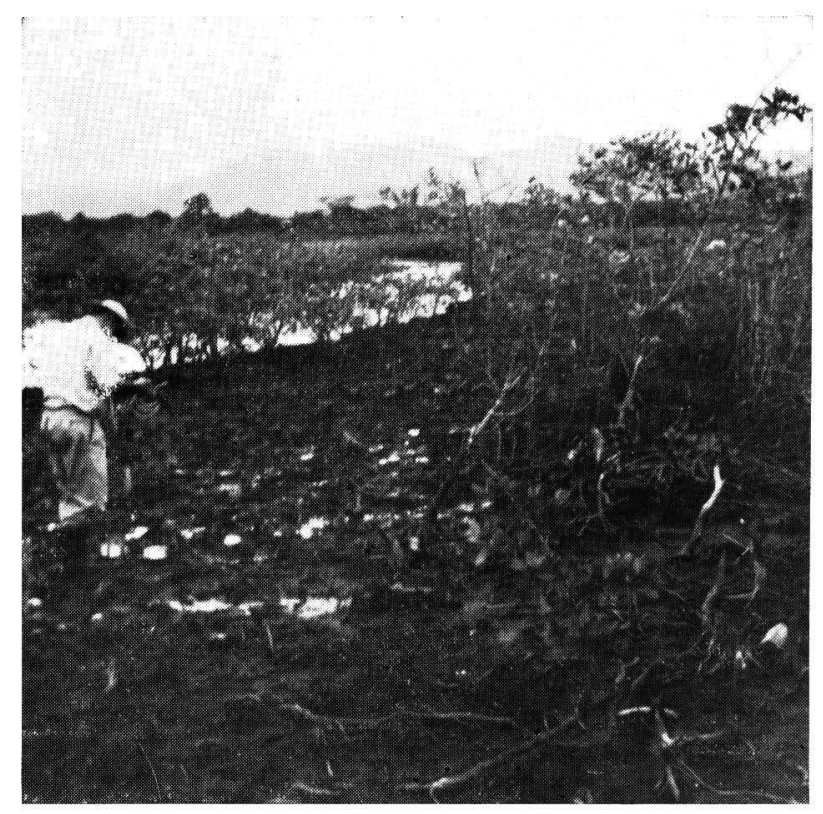

Fig. 30

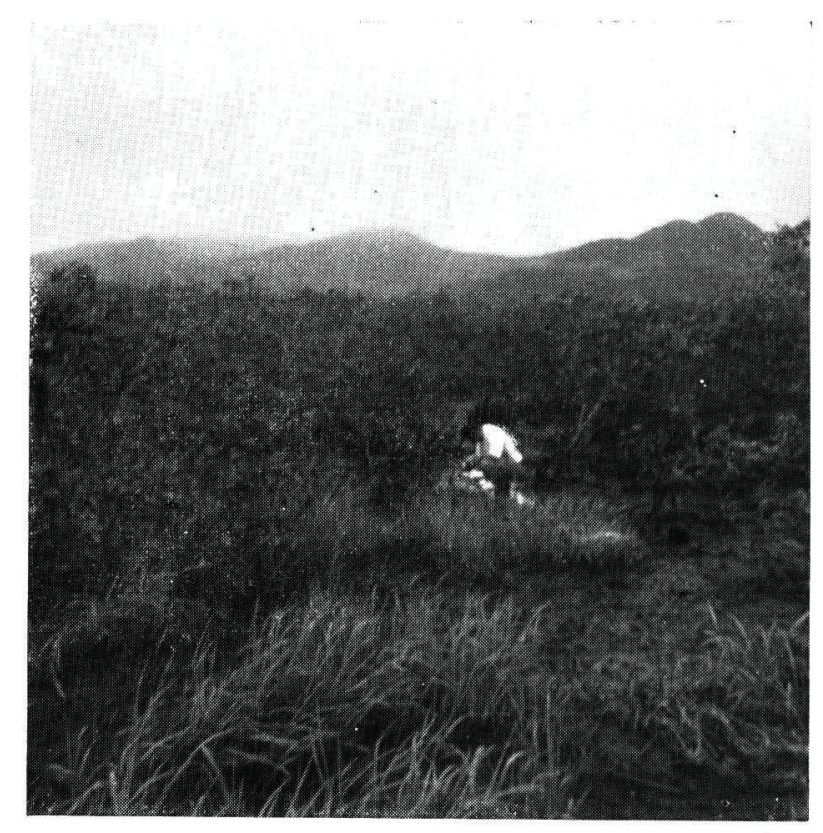

Fig. 31

Figs. 30 e 31 Áreas de mangue onde foram encontradas formas imaturas de $C$. maruim e de $C$. insignis. 
Pesquisas em coleções de água de terrenos secos - Como já tivemos ocasião de descrever, podemos considerar como terrenos secos aquêles que constituem a restinga e os que pertenciam ao "mangue" e sofreram posteriormente o processo de drenagem. Assim sendo, as coleções de água que neles encontramos são principalmente constituidas pelas valas abertas para drenagem e arruamentos, e poças líqüidas coletadas em diversas irregularidades do terreno. As valas sofrem, de maneira variável, a influência da água salgada, uma vez que formam, no seu conjunto, vasta rêde que se comunica direta ou indiretamente com os canais de água salgada. Assim sendo, quanto maior a proximidade dêstes, maior o teor salino das águas das valas. As mais afastadas apresentam, pràticamente, teor nulo de salinidade. As outras coleções são de água sem sal, que ficou empoçada em irregularidades diversas do terreno.

As pesquisas que levamos a efeito nesses locais, permitiu-nos encontrar criadouros de $C$. insignis e $C$. guyanensis. Ambas essas espécies foram encontradas em vários tipos de valas, possuindo água de teor alino variável, desde próximo ao da água do canal até pràticamente nulo. A primeira daquelas espécies foi também encontrada em outras coleções, como aquelas formadas em depressões de terreno provocadas por rodas de automóvel. As Figuras 32, 33, 34 e 35, dão idéia dêsses tipos de criadouros.

Pesquisas em buracos de carangueijos - Os carangueijos que encontramos podem ser divididos em duas categorias: a daqueles que habitam o "mangue" e terrenos secos artificialmente, e a daqueles que habitam terrenos elevados ou restinga. Os primeiros são constituidos por espécies pertencentes a vários gêneros, algumas das quais cavam buracos. As do gênero Ocypoda (Fig. 36), conhecidas vulgarmente pelo nome local de "Maria mulata", não fazem buracos. As do gênero Uca, das quais destacamos Uca vocator H., Uca uruguayensis N. e Uca leptodactyla R. (Fig. 37), recebem o nome vulgar de "chama maré", são muito numerosas e cavam pequenos buracos pouco profundos e intercomunicantes (Fig. 40). Ainda nesta categoria de habitantes do "mangue", temos a espécie que faz os maiores buracos, profundos e sinuosos, e a Oedipleura cordata H. (Fig. 38) que, em certas épocas do ano torna-se muito numerosa. Como dissemos, os buracos que esta espécie faz são largos e apreciàvelmente profundos (Figs. 40, 41, 42 e 43), com decurso tortuoso. Quando estão situados no "mangue", contém água salgada e permanecem submersos por ocasião das altas marés. Nos terrenos secos artificialmente, costumam conter água com teor salino menor. A segunda categoria de carangueijos cavadores de buracos, é constituida pela espécie Cardisoma guanhumi L. (Fig. 39) que habita os terrenos mais elevados, fora da ação das marés. Os buracos que esta espécie faz, são grandes e profundos (Figs. 44, 45 e 46). O canal é tortuoso e pode chegar a profundidades de cêrca de um metro ou mais. No fundo, o referido canal desemboca em grande câmara ou "panela", onde acumula notável quantidade de água de baixo teor salino. Em buracos 


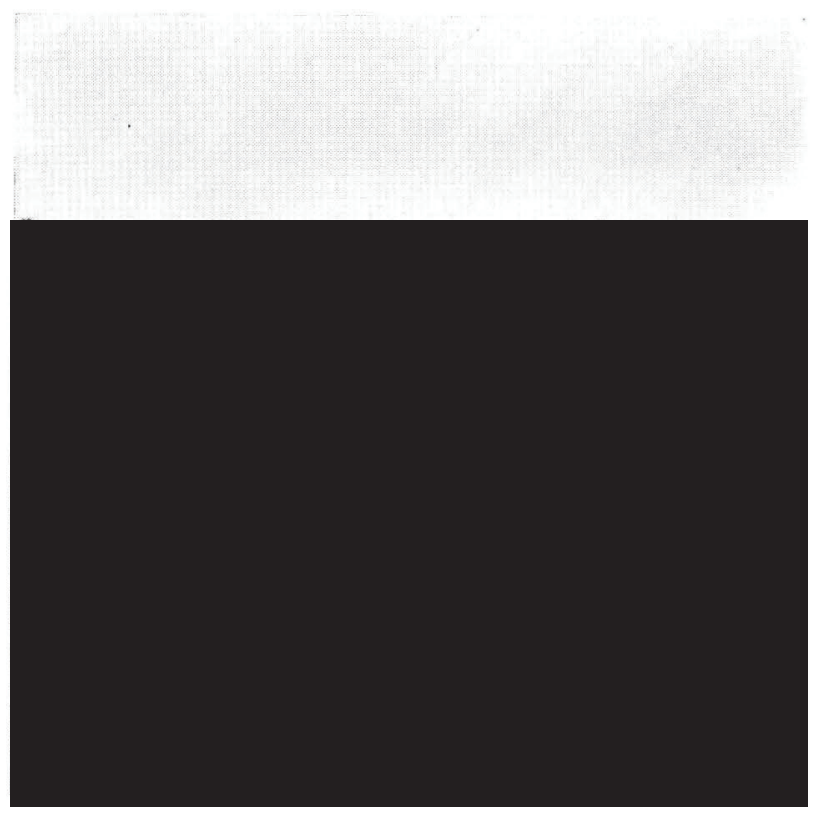

Fig. 32

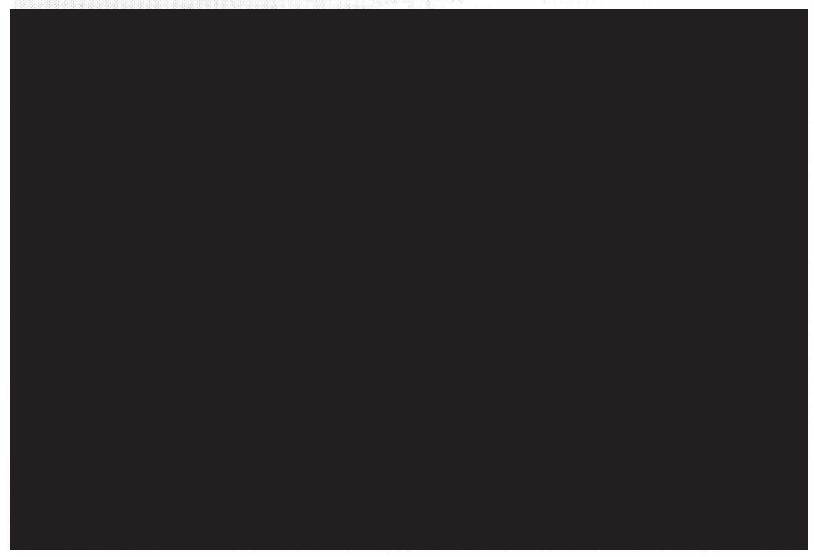

Fig. 33 


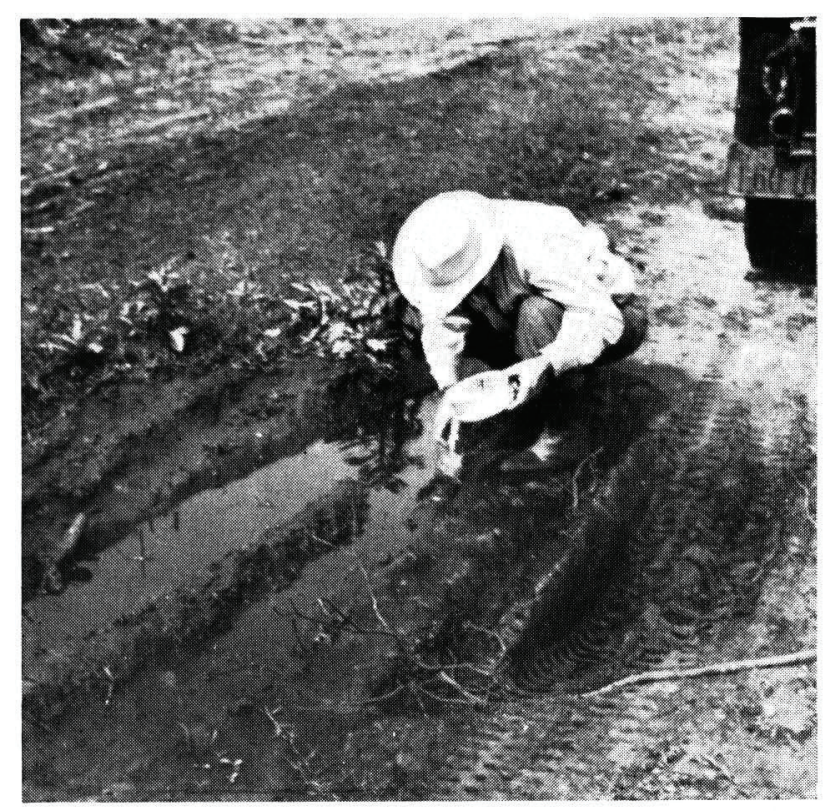

Fig. 34

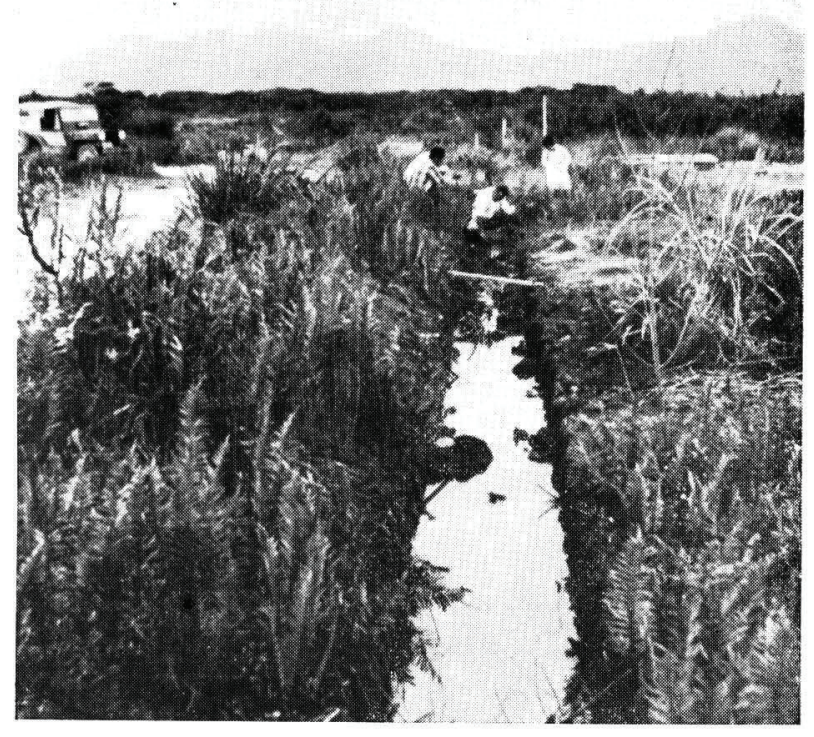

Fig. 35

Criadouros de Culicoides. Fig. 32 -Vala de drenagem contendo água com certo teor salino, onde foram encontradas formas imaturas de $C$. insignis; Fig. 33 - Vala de rua, criadouro de $C$. insignis; Fig. $34-$ Poça de água coletada em depressão produzida por rodas de automóvel, onde se encontrou larvas de $C$. insignis; Fig. 35 Vala de loteamento e drenagem, local de criação de $C$. guyanensis. 


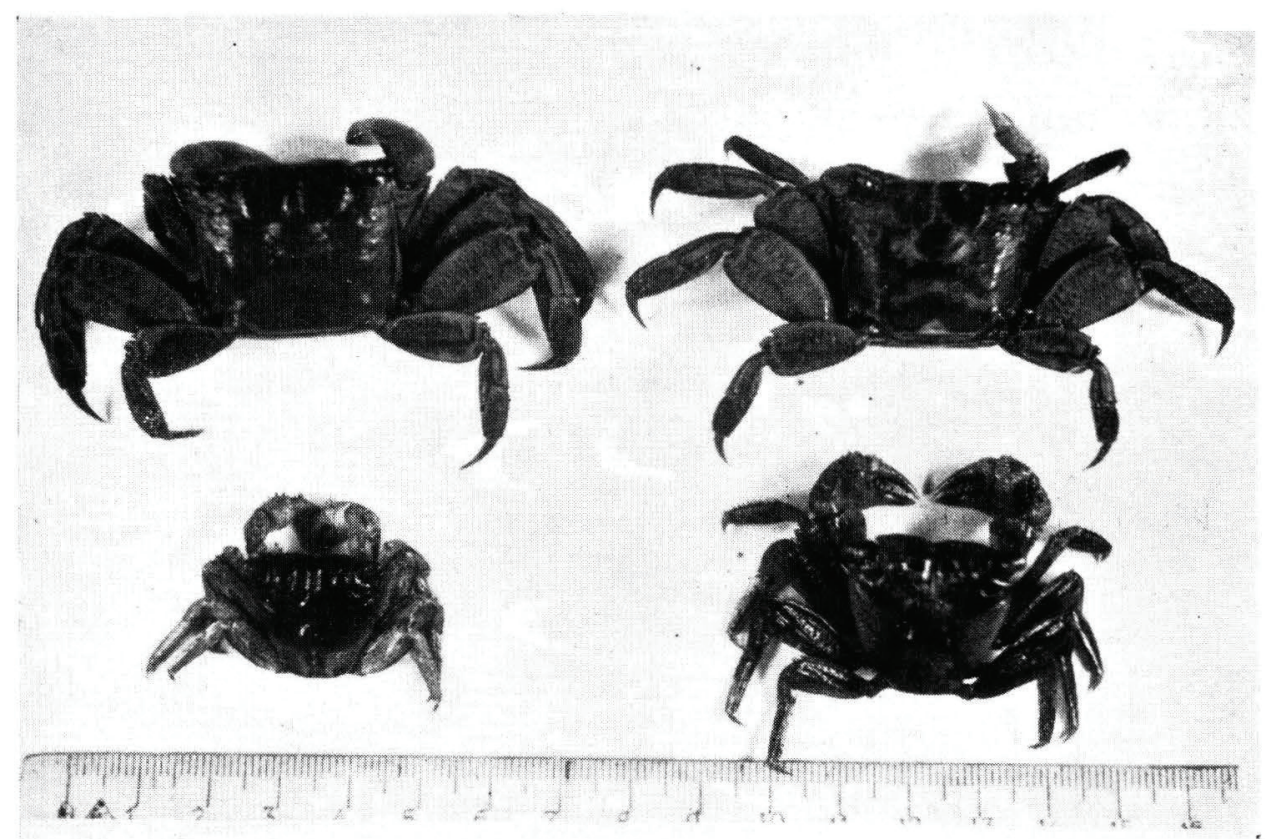

Fig. 36 - Espécies do gênero Ocypoda.

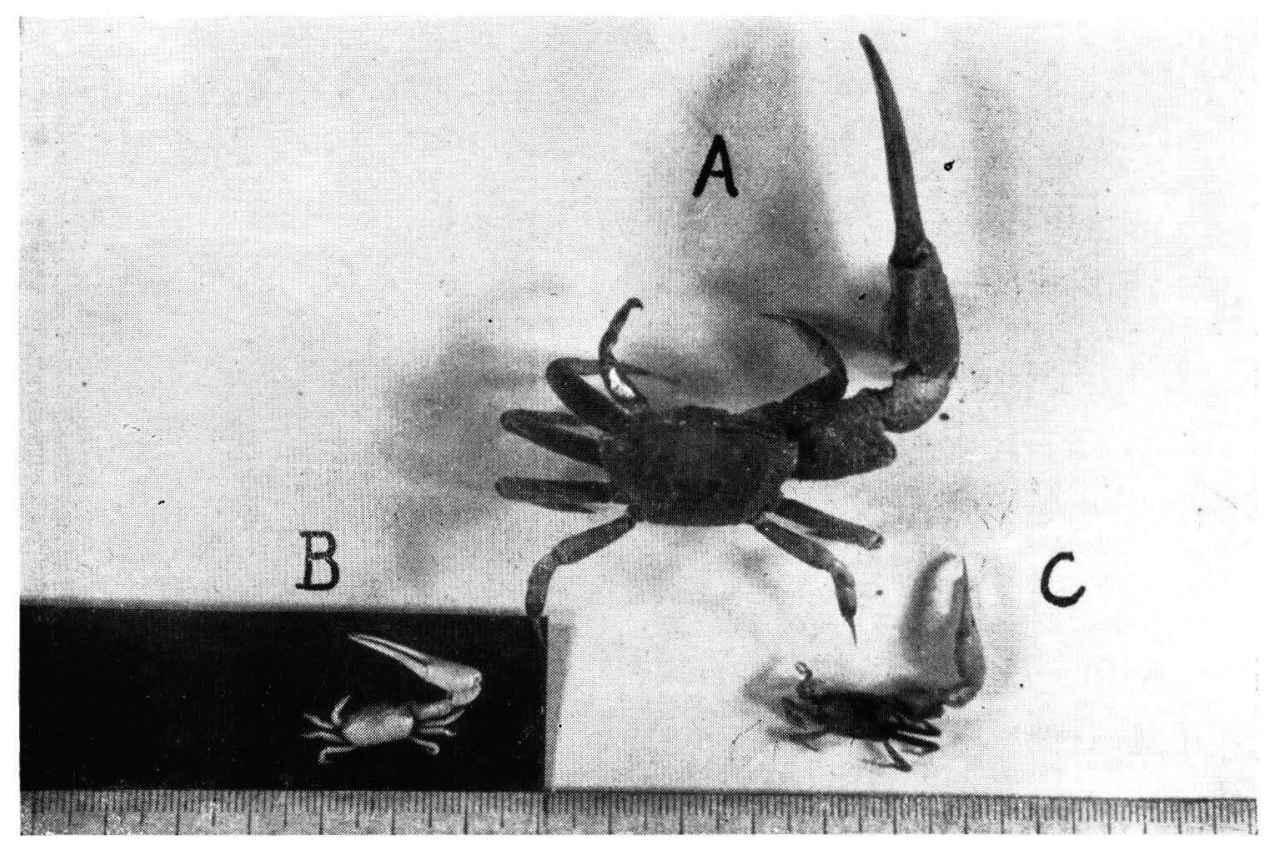

Fig. 37 - Espécies do gênero Uca: A - Uca vocator H., B - Uca uruguayensis N., $\mathrm{C}-$ Uca leptodactyla $\mathrm{R}$. 


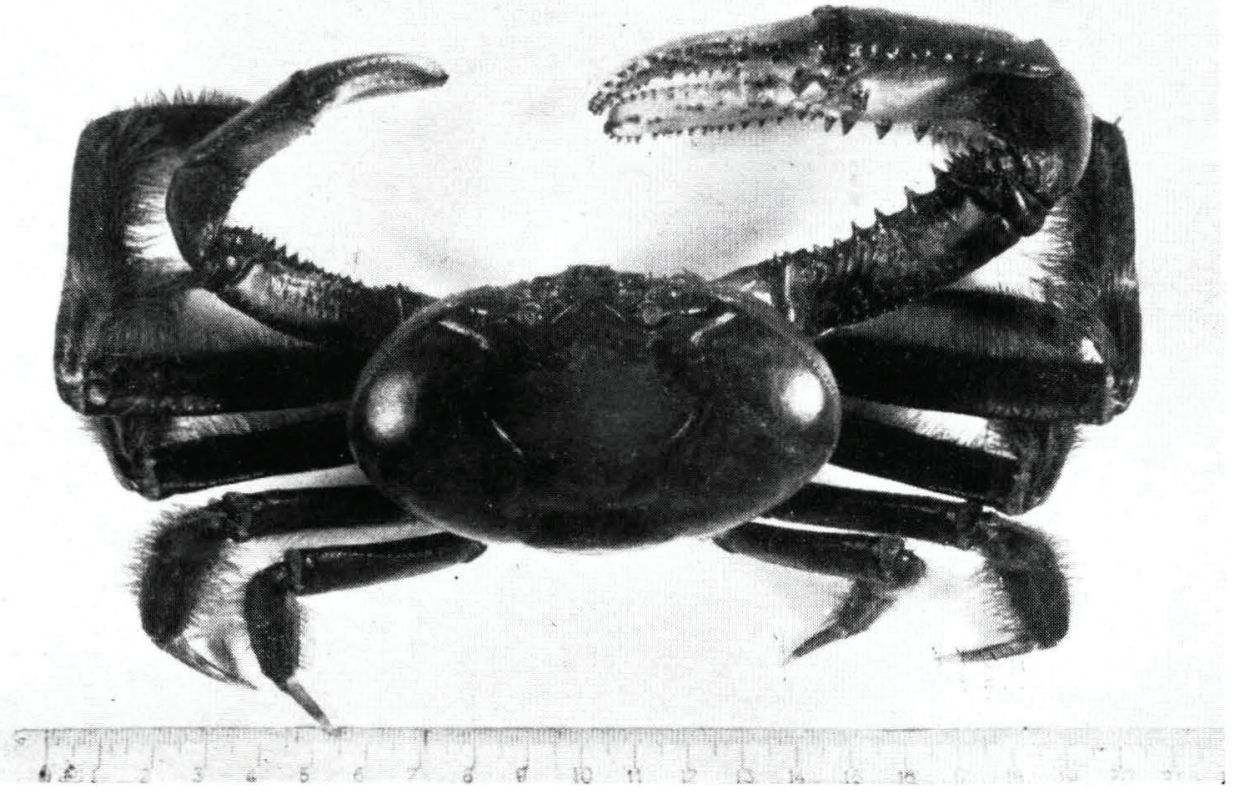

Fig. 38 - Oedipleura cordata H.

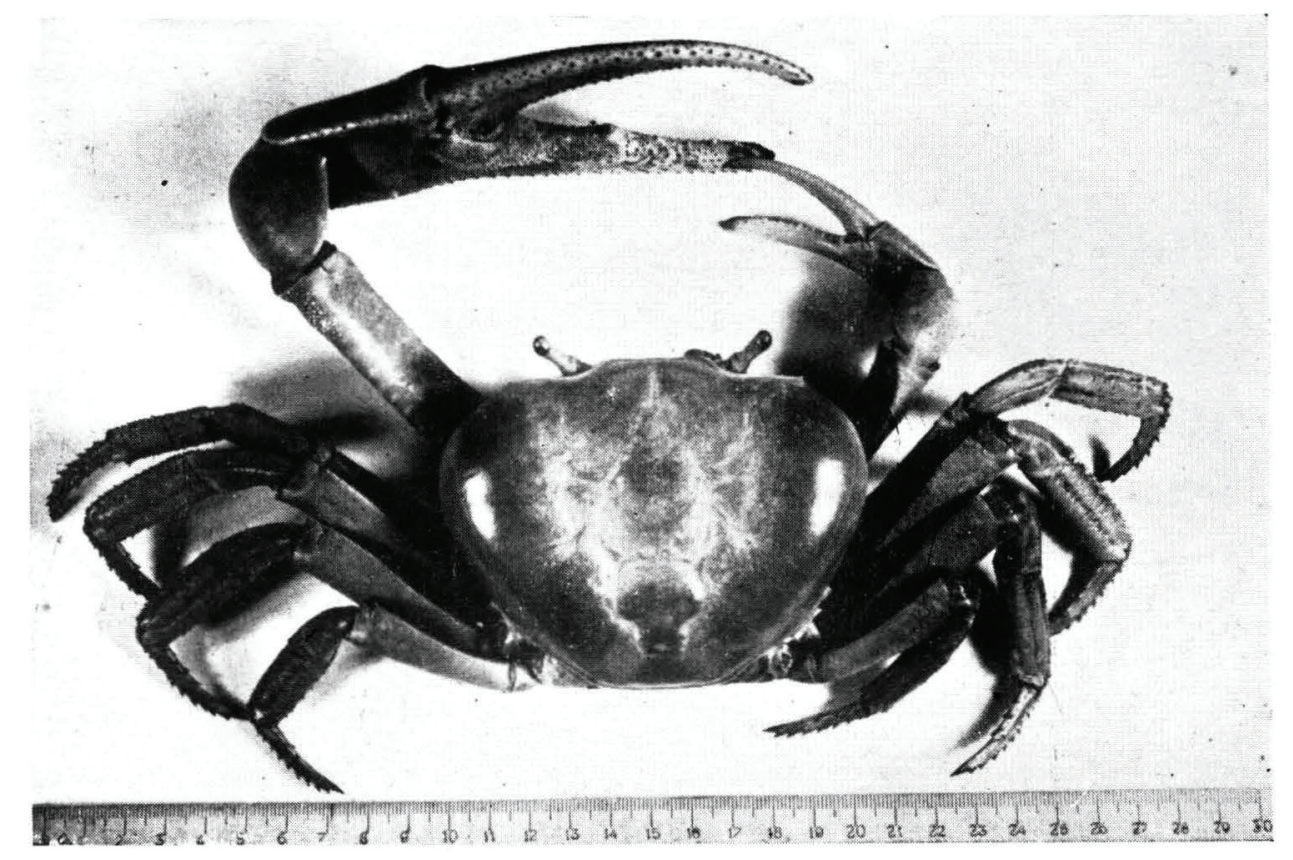

Fig. 39 - Carisoma guanhumi L. 


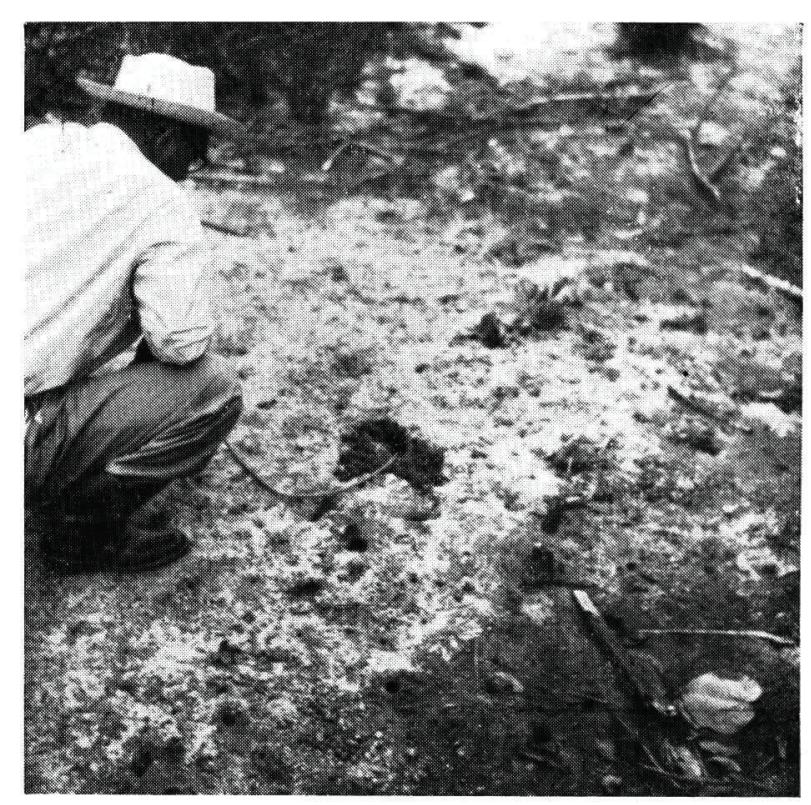

Fig. 40

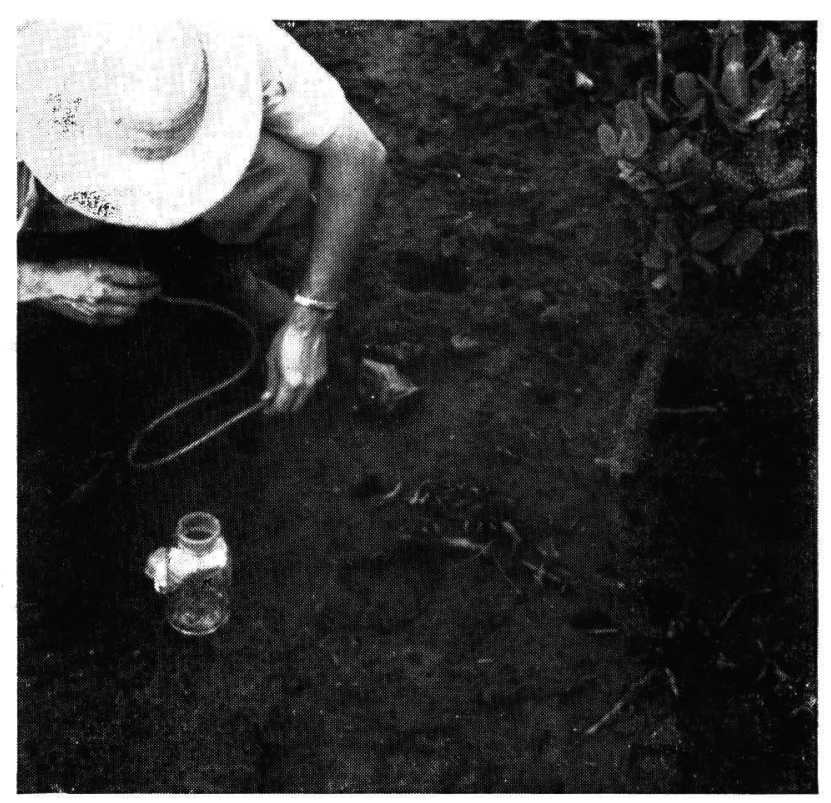

Fig. 41 


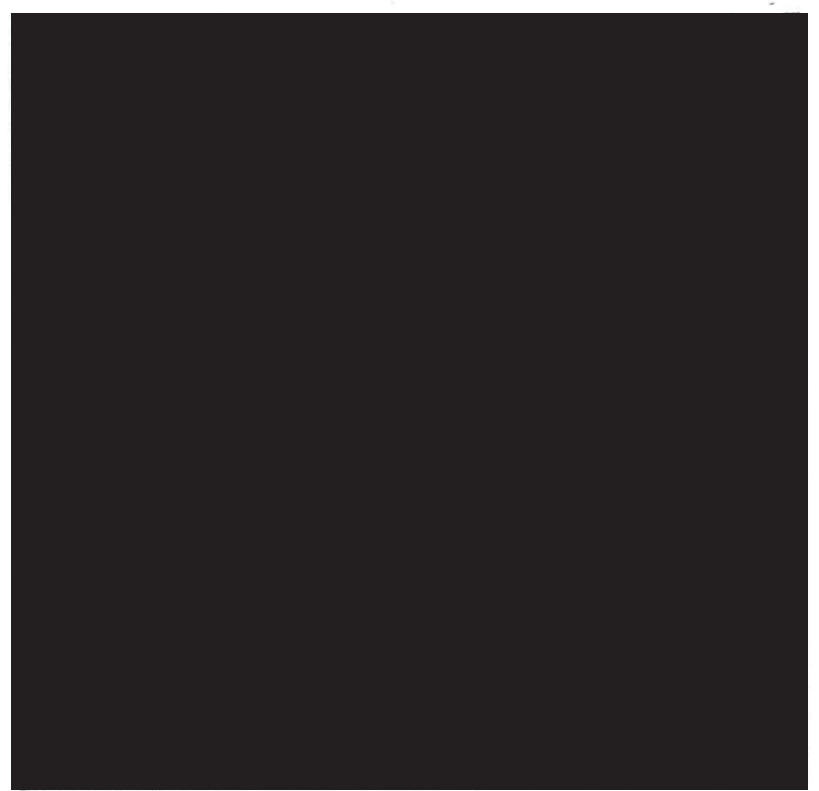

Fig. 42

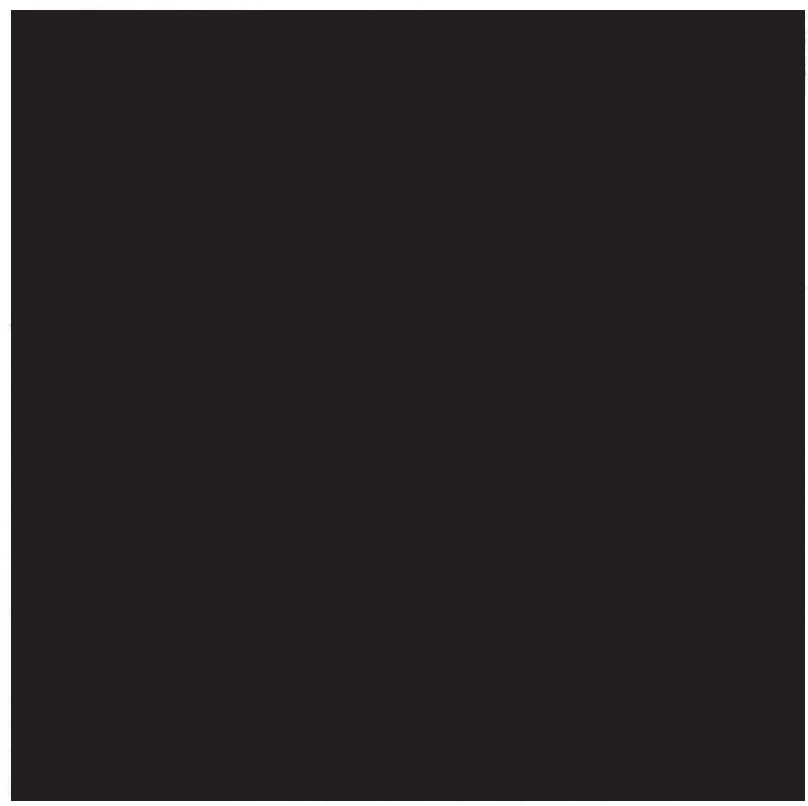

Fig. 43

Buracos de carangueijos do mangue. Fig. 40 - Buracos de Oedipleura cordata ao lado de outros menores do gênero Uca; Figs. 41, 42 e 43 - Buracos de Oedipleura cordata, onde foram encontradas formas imaturas de $C$. insignis. 


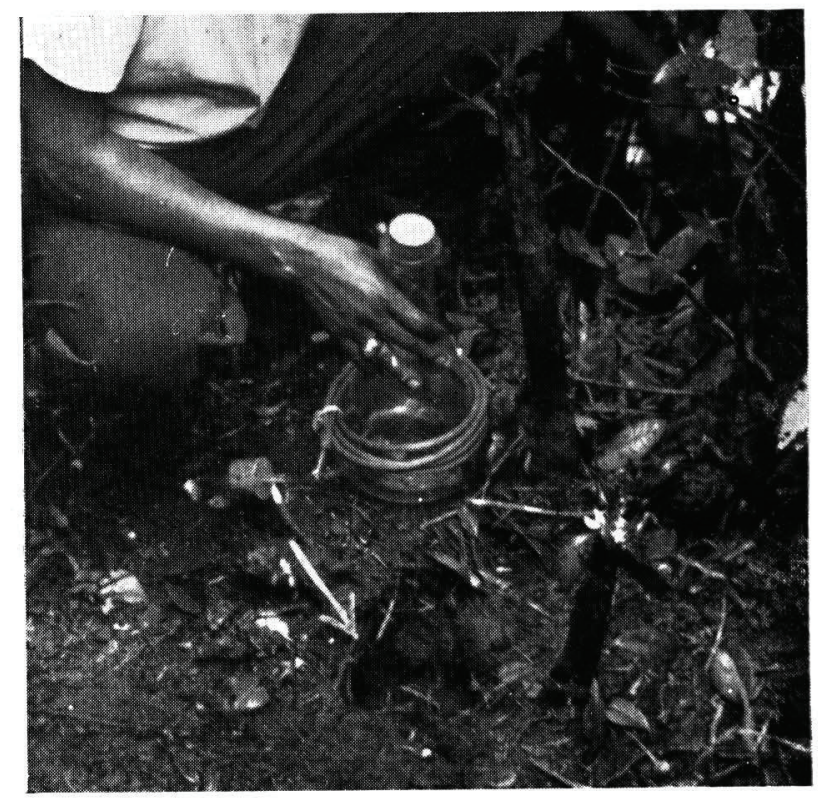

Fig. 44

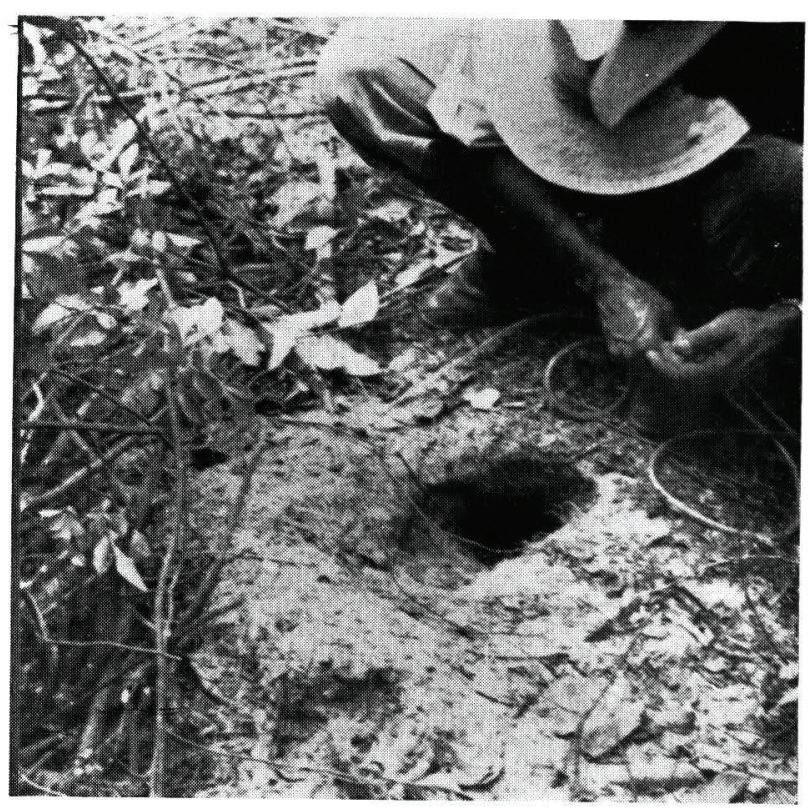

Fig. 45 
por nós pesquisados, chegamos em alguns casos a recolher aproximadamente dez litros de água.

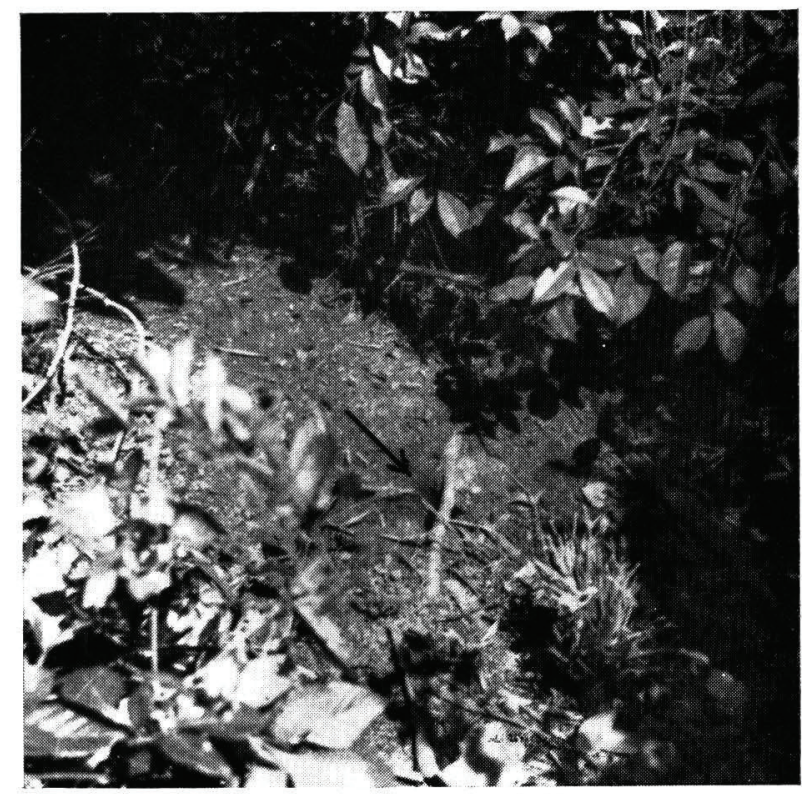

Fig. 46

Figs. 44,45 e 46 - Buracos de Cardisoma gutanhumi, local de criação de $C$. reticulatus.

Utilizando os métodos descritos anteriormente, conseguimos encontrar formas imaturas de $C$. insignis em buracos de Oedipleura cordata (Figs. 41, 42 e 43) situados em terrenos artificialmente secos. As investigações em buracos de Cardisoma guanhumi revelaram a presença de larvas e pupas de C. reticulatus (Figs. 44, 45 e 46) o qual; como já tinha sido assinalado por Lutz ${ }^{26}$ (1912), parece ter-se adaptado a êsse tipo de criadouro, juntamente com várias espécies de Culicideos como Culex (C.) carcinoxenus, Aedes (O.) taeniorhynchus e Aedes (O.) perventor.

\section{OBSERVAÇÕES SÔBRE O COMPORTAMENTO DOS ADULTOS}

Nos arredores de São Vicente, tentamos colher dados que pudessem orientar sôbre melhor conhecimento do comportamento das formas aladas de Culicoides. Nesse sentido procuramos observar a freqüência domiciliar, os hábitos hematófagos, a densidade e variação estacional durante os meses do ano. Devemos assinalar que, nas nossas coletas, verificamos o predomínio pràticamente total das fêmeas. $\mathrm{O}$ número de indivíduos machos foi irrisório. A explicação desse fato nos escapa. Parece existir a êsse respeito, diferenças de comportamento conforme as espécies. Assim, Mirsa ${ }^{28}$ (1953), realizando capturas nos arredores de Caracas, Venezuela, obteve o predomínio de machos em $C$. pusillus e de fêmeas nas outras espécies. 
Nas nossas coletas com isca animal devia-se, realmente, esperar maior número de indivíduos femininos. Em vista disso, e com o objetivo de obter machos, levamos a efeito capturas com isca luminosa. Todavia, os resultados foram pràticamente os mesmos. Seja como fôr, podemos pensar que, para determinadas espécies, os machos tenham pouca ou nenhuma tendência a abandonar a vizinhança dos criadouros.

\section{Freqüência domiciliar}

Como já tivemos ocasião de mencionar, a maior atividade dos "maruins" se realiza no ambiente extra-domiciliar. Contudo, podem ser encontrados no interior das habitações. Mirsa ${ }^{28}$ (1953) realizando capturas intradomiciliares, obteve numerosas espécies com predominio de $C$. pusillus. Em ocasiões diversas, conseguimos coletar exemplares no interior de habitação da região onde trabalhamos. Tais coletas foram realizadas em uma casa distante cêrca de 500 metros das armadilhas, e em 15 ocasiões foram feitas capturas noturnas dêsses dípteros. Obteve-se assinı, um total de 752 exemplares, distribuidos pelas seguintes espécies:

\begin{tabular}{c|c|c}
\hline \multicolumn{1}{c|}{ Espécie } & N. & Média por captura \\
\hline C. insignis $\ldots \ldots \ldots \ldots \ldots$ & 597 & 39,80 \\
C. maruim $\ldots \ldots \ldots \ldots \ldots$ & 113 & 7,53 \\
C. guyanensis $\ldots \ldots \ldots \ldots$ & 42 & 2,80 \\
\hline Total ............... & 752 & 50,13 \\
\hline
\end{tabular}

Vemos pois que, em certas condições, os "mosquitos-pólvora" podem ser encontrados freqüentando os domicílios. Embora as nossas observações nesse particular sejam pequenas e não permitam maiores conclusões, podemos assegurar que êles se mostram mais ativos no ambiente extra-domiciliar. A tendência em freqüentar as casas está relacionada com a localização das moradias, na vizinhança dos criadouros.

\section{Hematofagia}

As atividades hematófagas dos Culicoides não tem sido objeto de investigações sistemáticas com a finalidade de determinar a preferência alimentar das diferentes espécies. Contudo, várias delas foram observadas sugando 0 homem (Lutz ${ }^{27}$, 1913, Nicholas et al. ${ }^{30}, 1953$, Snow ${ }^{34}, 1955$, Williams ${ }^{33}$, 1955, Snow, Pickard e Jones ${ }^{35}, 1958$ ), animais domésticos (Lutz ${ }^{27}, 1913$, Carpenter ${ }^{3}, 1951$ ), macacos (Haddow e Dick ${ }^{18}, 1948$ ) e aves (Davis ", 1944, Snow, Pickard e Jones ${ }^{35}, 1958$ ). Todavia, parece não haver evidência de preferências alimentares acentuadas para êste ou aquêle animal, pelo menos nas espécies mais comuns. Nos arredores de São Vicente observamos 
C. insignis, C. maruim, C. guyanensis e C. flavivenula sugando o homem, e as três primeiras sugando também cabra, cavalo e cão. $O$ C. maruim constitui, nessa região, o verdadeiro "mosquitinho-do-mangue", atacando insistentemente o homem e animais que freqüentam os terrenos pantanosos de água salgada onde tem seus criadouros. Fora dêsse ambiente, diminui sensivelmente de atividade e a hematofagia passa a ser exercida, predominantemente, pelas outras espécies.

\section{Incidência}

A densidade e variação estacional dos Culicoides foram objeto de muitas investigações. Para isso, na Região Neotropical, usou-se principalmente de armadilhas com isca luminosa. Como já tivemos ocasião de referir, nos nossos trabalhos utilizamos armadilhas tipo Shannon, com isca animal e, de maneira transitória, com isca luminosa. Em tôdas essas observações procuramos obter dados que pudessem elucidar a ação dos diferentes fatôres sôbre a densidade dêsses dipteros.

Influência das marés - Lutz ${ }^{26}$ (1912), nos arredores do Rio de Janeiro, observou maior densidade de Culicoides, por ocasião das luas Cheia e Nova. Procurou então, êsse autor, relacionar o fenômeno com o movimento das marés concluindo que, embora a densidade maior possa coincidir com as marés altas, êsse aumento indicaria principalmente a influência das marés vasias. Todavia, é o mesmo autor que, considerando a provável ação de muitos outros fatôres, admite o valor apenas aproximado daquela conclusão “. . não sendo raras as observações contraditórias". Hull, Dove e Prince ${ }^{20}$ (1934) sugerem a possibilidade de que certo dessecamento parcial estimularia a pupação das larvas e a saída dos adultos, dentro de poucos dias. Woke 4: (1954) trabalhando nos arredores de Balboa, Panamá, procurou verificar a influência das marés, comparando a freqüência de inundação dos terrenos com a obtenção de larvas de Culicoides (principalmente C. furens). Como resultado, observou certa tendência para diminuição da incidência dessas larvas com o aumento da submersão pela maré. E, embora muitos outros fatôres devam ser levados em consideração como a freqüência, duração e profundidade da cobertura aquática, a contextura, temperatura e grau de saturação do lodo, a presença ou ausência de vegetação, o referido autor encontra evidência para supôr que o desenvolvimento das larvas não deva ocorrer nas áreas pantanosas que são cobertas pelas marés, duas vêzes ao dia. Assim sendo, vemos que essa conclusão vai ao encontro da de Lutz ${ }^{2 \beta}$ (1912). Com efeito, é de se admitir que as marés baixas, deixando maior porção de terreno pantanoso sem cobrir, provoquem maior eclosão de adultos. A falta de cobertura aquática agiria como estímulo para as larvas se transformarem em pupas. Sendo o período pupal muito curto, teríamos logo após, a produção de alados. Com o intúito de verificar a existência de alguma relação nesse sentido, calculamos as médias horárias obtidas na armadilha com isca animal durante o ano de 1956. Inicialmente, 
tais médias foram calculadas para o número total de Culicoides, divididos nos periodos de alta e baixa marés, correspondentes pois, às épocas de lua cheia e nova dos diversos meses. O resultado, colocado em gráfico, está representado na Figura 47. Como se pode ver, parece não existir relação uniforme entre tais períodos e a densidade dos dipteros. Sòmente para o lapso de tempo que inclui o mês de maio e o começo de junho, observa-se certo aumento coincidindo com as épocas das altas marés. No restante, o comportamento é de tal forma irregular que, por êsses dados, torna-se muito dificil chegar a alguma conclusão. Em vista disso, resolvemos calcular as médias horárias referentes apenas às capturas de $C$. maruim. Adotamos tal atitude baseados no fato de que essa espécie é habitante essêncıal dos "mangues", onde parece ter, de maneira exclusiva, seus criadouros. Assim sendo, se deve haver alguma influência das marés, ela deverá se fazer sentir com maior intensidade nesta espécie do que nas outras que possuem outros tipos de criadouros, fora dos "mangues". Assim pois, os valores dessas médias horárias, calculados dia a dia durante todo o ano de 1956, foram colocados em gráfico, juntamente com os representativos da preamar e da baixamar. O resultado está representado na Figura 48. Desta vez, a observação do gráfico parece sugerir certa concordância entre os periodos de alta maré e a densidade de $C$. maruim.. Com efeito, a linha das médias horárias, com raras discrepâncias, mostra seus valores máximos por ocasião das altas marés. Dessa forma, se levarmos em consideração que o tempo pupal é curto, ou seja, de poucos dias de duração, veremos que se torna fácil supôr que o aumento do número de adultos dessa espécie reflete a influência das baixas marés, que precedem as altas. Em suma, acreditamos que Lutz ${ }^{26}$ (1912) tinha razão quando afirmava que o aumento de Culicoides indicava principalmente a ação das marés baixas. Como já dissemos linhas atrás, a diminuição da cobertura aquática provocaria a formação de pupas e a subseqüente saida dos adultos. Evidentemente, não podemos deixar de levar em consideração todos os outros fatôres que podem influir na densidade dos "maruins" e mesmo, na seqüência das próprias marés. É sabido que estas, no nosso hemisfério, sofrem a açāo das condições meteorológicas. De qualquer forma porém, julgamos que não estaremos elaborando em grande erro se admitirmos que os movimentos da água do mar influem sôbre a produção das espécies que tem seus criadouros nos terrenos pantanosos marinhos.

Variação estacional - No nosso meio podemos encontrar diferenças nos vários meses do ano. Tais diferenças permitem dividir êsses meses em dois periodos principais: o dos meses quentes e chuvosos e o dos frios e secos. O primeiro teria o seu valor máximo de dezembro a fevereiro, e o segundo de junho a agôsto. Esta regra, todavia, pode sofrer algumas variações de ano para ano. De modo especial, na região litoranea do Estado de São Paulo, onde as precipitações atmosféricas são mais freqüentes e a temperatura média é mais elevada do que nas demais regiōes do Estado. 


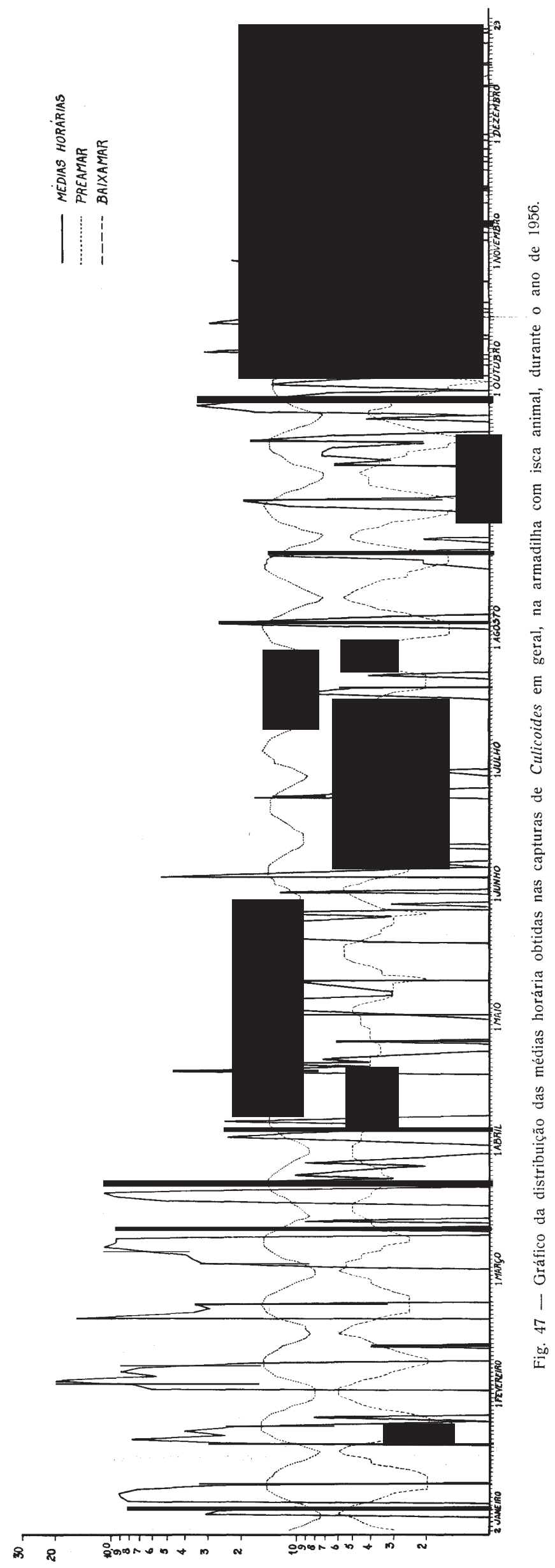




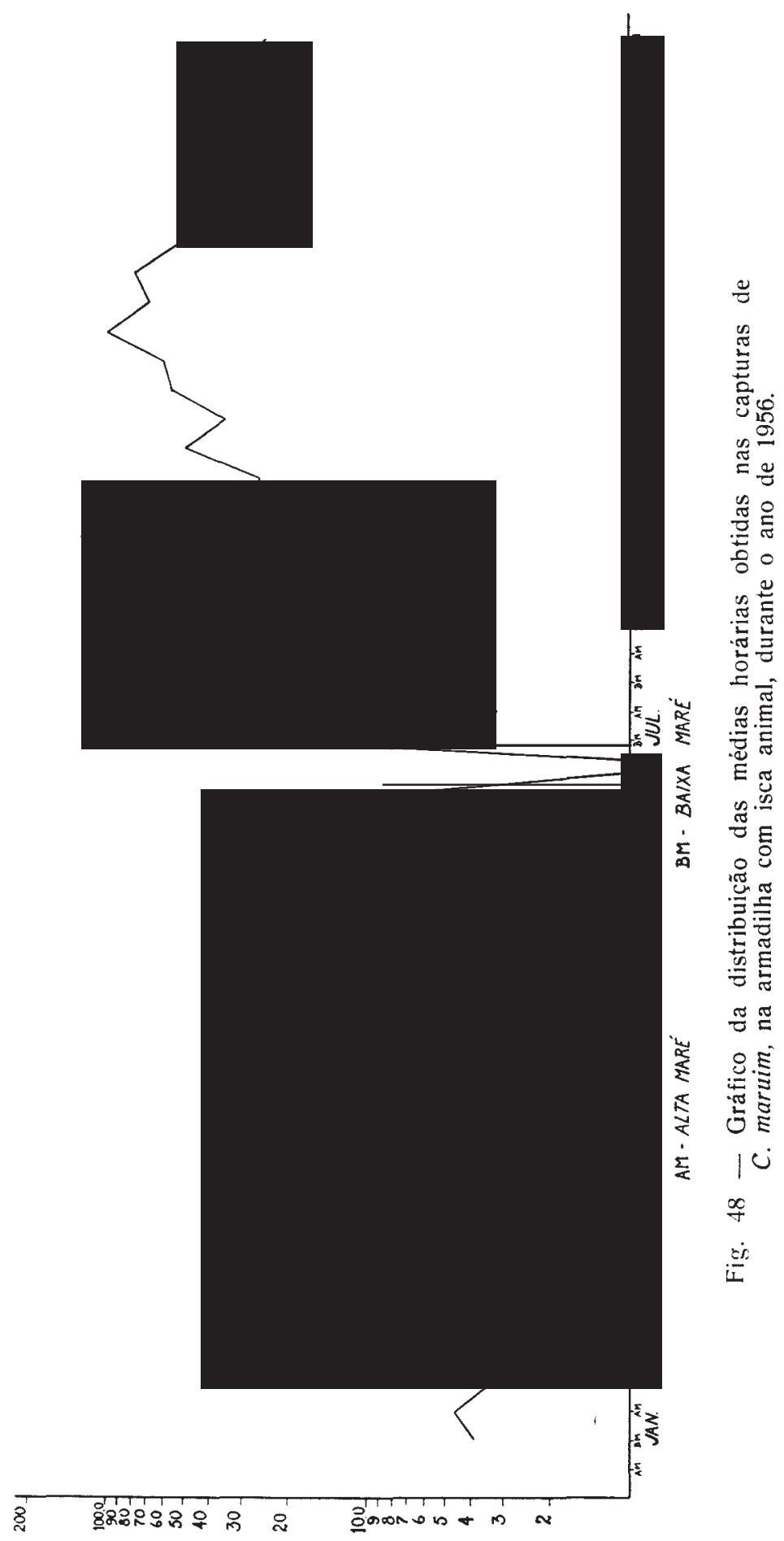




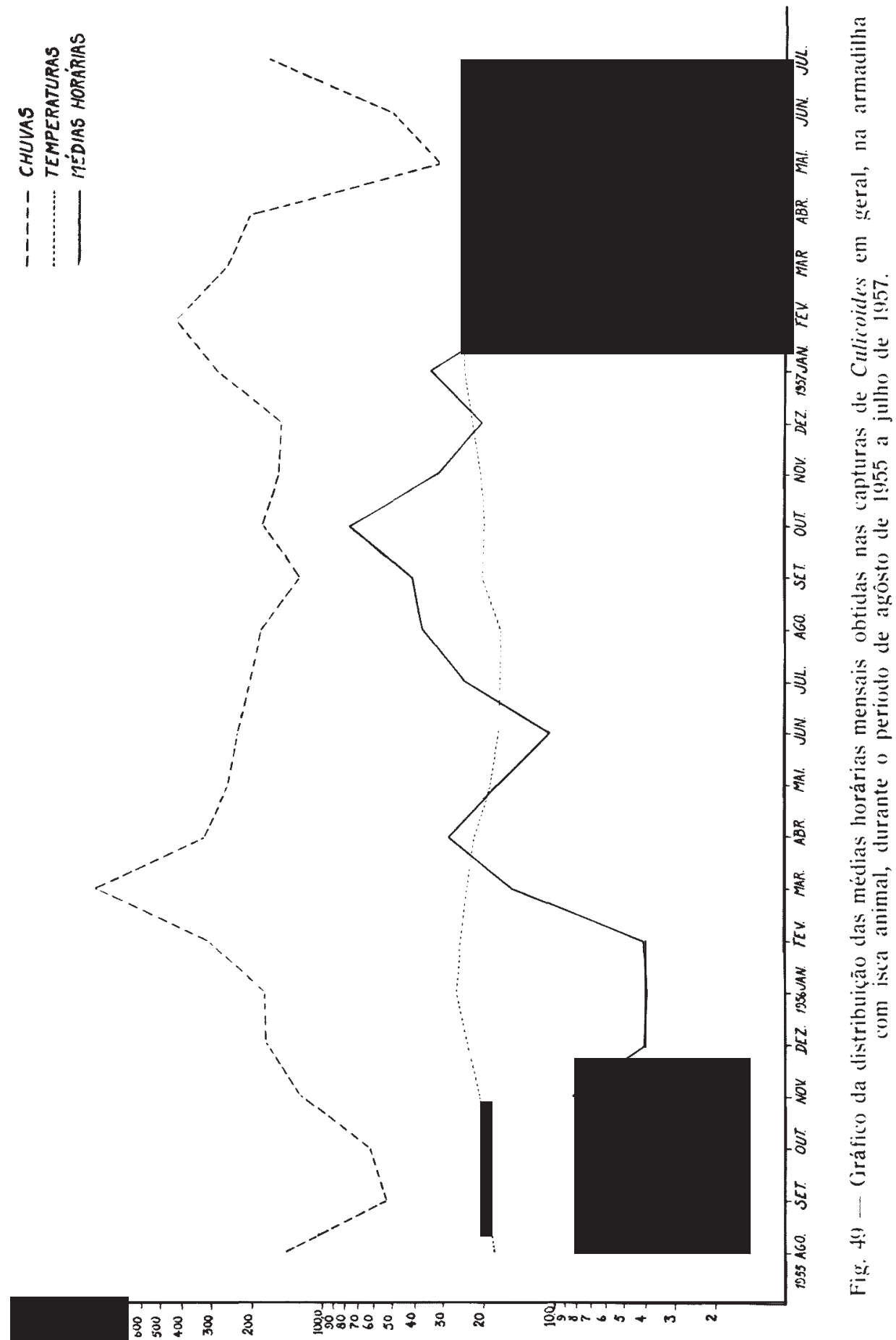


Dessa forma, torna-se comum a observação de discrepâncias na variação estacional da densidade dos Culicoides, como veremos mais adiante. Em regra geral porém, a maior produção dêsses dipteros corresponde aos meses quentes e úmidos, e a menor aos frios e secos. Ressalvados os casos de variação específica onde influem outros fatôres como, locais de criação, marẻs, etc., tais foram os resultados gerais a que chegaram as investigações de Carpenter ${ }^{3}$ (1951), Fox ${ }^{14}$ (1953), Fox e Maldonado Capriles ${ }^{16}$ (1953) e Mirsa ${ }^{2 \times}$ (1953), para citar sòmente as observações levadas a efeito na Região Neotropical. A questão das variações específicas deve ser apreciada quando se trata de estudar determinada espécie em particular. Assim, Fox ${ }^{14}$ (1953) e Fox e Maldonado Capriles ${ }^{16}$ (1953) observaram que as chuvas podem não ter influência sôbre a densidade de $C$. furens ao passo que exercem ação na produção de $C$. insignis $(=C$. inamollae $)$. Por outro lado, Mirsa ${ }^{2:}$ (1953) verificou, nos arredores de Caracas, que o máximo das capturas específicas correspondiam a diferentes meses para as diversas espécies. Vemos pois que a biologia particular de cada espécie pode influir no sentido de alterar a regra geral acima citada.

Nas nossas observações, como já foi dito, trabalhamos principalmente na armadilha com isca animal a qual funcionou initerruptamente, de agôsto de 1955 a julho de 1957, totalizando assim, 24 meses de coletas diárias. Os resultados, gerais e específicos, estão representados na Tabela 2 . Outra armadilha, com isca luminosa, funcionou de março a novembro de 1956, com interrupção por motivos locais, correspondente ao mês de julho do mesmo ano. O objetivo de termos usado também êste tipo de captura foi o de verificar se, mudando a isca, poderíamos obter maior número de indivíduos masculinos. Contudo, como já mencionamos, o número de exemplares dêsse sexo foi igualmente irrisório, de forma que êles nem mereceram entrar no computo das coletas. Os resultados desta armadilha estão representados na Tabela 3 .

A análise dos dados obtidos com isca animal (Tabela 2), mostra considerável variação nos resultados conseguidos de mês para mês e de ano para ano. As médias horárias mensais e os dados meteorológicos de temperatura e precipitação atmosférica constantes da Tabela 1, dispostos em gráfico, forneceram o aspecto representado pela Figura 49. Embora a presença de considerável variação, na qual intervém certamente, numerosos fatôres gerais e específicos, podemos verificar que existe certa tendência para diminuição das médias nos meses frios e secos, isto é, de junho a agôsto. No mês de junho de 1957, os Culicoides chegaram mesmo a desaparecer das capturas. Em resumo, podemos dizer que existe certa variação estacional caracterizada, em linhas gerais, por maior produção de adultos nas épocas de maior temperatura e de maiores precipitações atmosféricas.

A Tabela 3 reflete os resultados alcançados na armadilha com isca luminosa. Tais dados não nos permitem observar, de maneira evidente, a citada variação estacional. Um fato porém chamou a nossa atenção. 


\begin{tabular}{|c|c|c|c|c|c|c|c|c|c|c|c|c|}
\hline & 2 & $\stackrel{\infty}{n} \stackrel{\infty}{=}=$ & $\tilde{N} \vec{E}$ & 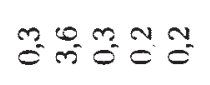 & $\Xi=$ & $\stackrel{x}{\varrho}$ & $\stackrel{x}{\circ}$ & $\stackrel{x}{=}$ & 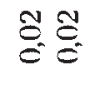 & 1 & 总 & $\cong$ \\
\hline 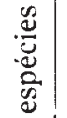 & $\dot{z}$ & 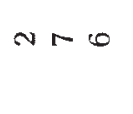 & $\varrho N$ & $\sim \mathcal{N} N--$ & $=+$ & - & - & - & -- & 1 & $m$ & N \\
\hline 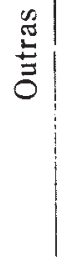 & 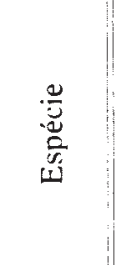 & 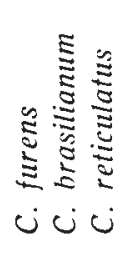 & 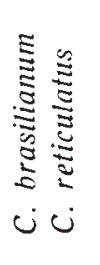 & 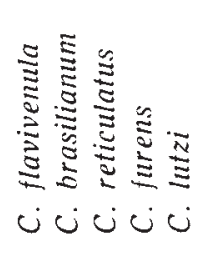 & 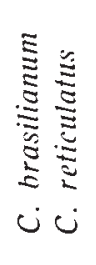 & 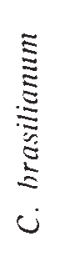 & 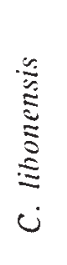 & ن & 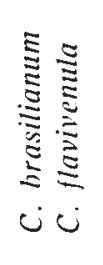 & 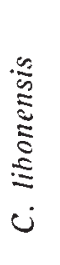 & 1 & 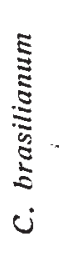 \\
\hline 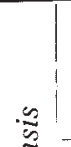 & 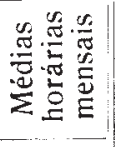 & $\tilde{c}$ & $\tilde{c}$ & $\stackrel{8}{E}$ & 3 & $\stackrel{0}{E}$ & $\stackrel{x}{=}$ & $\stackrel{m}{=}$ & 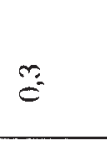 & $\stackrel{\cong}{\mathscr{E}}$ & E & $\frac{8}{0}$ \\
\hline 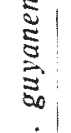 & $\approx$ & $\stackrel{m}{\simeq}$ & $\begin{array}{l}\infty \\
\stackrel{\infty}{N}\end{array}$ & 7 & $\stackrel{0}{=}$ & 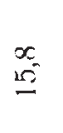 & $\stackrel{\tilde{\pi}}{\check{\pi}}$ & $\stackrel{v}{\sim}$ & $\underset{\sim}{i}$ & $\bar{E}$ & $\sigma_{0}$ & $\cong$ \\
\hline & $\dot{z}$ & $\stackrel{\infty}{F}$ & 8 & $\nexists \mathbb{i}$ & $\underset{\ddagger}{\ddagger}$ & $\Xi$ & مُ & $\mathscr{\check { \varkappa }}$ & : & $\subseteq$ & $\stackrel{2}{2}$ & $r$ \\
\hline$E$ & 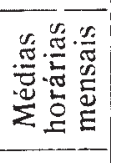 & $\overline{0}$ & $\tilde{\sigma}$ & $\stackrel{\infty}{\circ}$ & $\Xi$ & $\bar{v}$ & $\bar{i}_{i}$ & $\stackrel{c}{\sim}$ & is: & $\stackrel{8}{8}$ & $\stackrel{5}{8}$ & $\stackrel{m}{\Leftrightarrow}$ \\
\hline 苟 & $\approx$ & i & $\stackrel{N}{\varrho}$ & $\stackrel{20}{F}$ & $\bar{E}$ & $\frac{7}{15}$ & ָ̃ & c & $\stackrel{m}{\varrho}$ & $\stackrel{\infty}{=}$ & $\bar{m}$ & a \\
\hline & $\dot{z}$ & ஜ్ల & ร & 怘 & 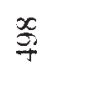 & 㲐 & $\frac{50}{6}$ & $\stackrel{\varepsilon}{尺}$ & $\stackrel{N}{F}$ & 范 & $\stackrel{N}{I}$ & 8 \\
\hline & 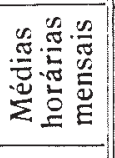 & $=$ & $\cong$ & $\cong$ & $\stackrel{1}{i n}$ & $=$ & $\stackrel{\simeq}{=}$ & $\stackrel{-1}{=}$ & $\stackrel{\text { š }}{\stackrel{5}{=}}$ & 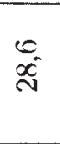 & $\bar{\Xi}$ & $\stackrel{10}{0}$ \\
\hline 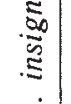 & 20 & 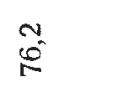 & $\stackrel{+}{i}$ & 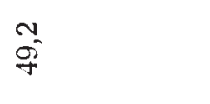 & $\overline{\tilde{c}}$ & î & $\overline{\bar{\rho}}$ & $\widehat{\vec{x}}$ & $\overline{\bar{x}}$ & $\bar{x}$ & 8 & $\ddot{8}$ \\
\hline & $\ddot{z}$ & $\stackrel{\infty}{\stackrel{N}{N}}$ & $\underset{m}{\vec{m}}$ & ஜ్ & $\bar{E}$ & 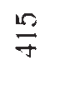 & $\underset{\varpi}{\mathscr{\varpi}}$ & 声 & 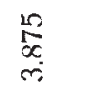 & $\begin{array}{l}\vec{J} \\
\stackrel{\circ}{\circ} \\
\infty\end{array}$ & 忘 & 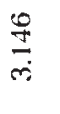 \\
\hline 氶 & 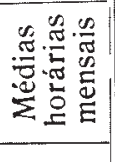 & $\stackrel{\Xi}{=}$ & $\stackrel{0}{=}$ & $\stackrel{\sim}{\sim}$ & $\vec{x}$ & $\bar{F}$ & $\stackrel{\odot}{\mp}$ & $\bar{F}$ & 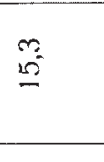 & ڤ్̀ & $\stackrel{\Xi}{=}$ & $\stackrel{\infty}{\subseteq}$ \\
\hline $\begin{array}{l}\text { 吾 } \\
\stackrel{5}{\circ} \\
\end{array}$ & $\ddot{z}$ & $\vec{\rho}$ & $\tilde{\mathscr{o}}$ & $\frac{0}{6}$ & 离 & 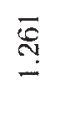 & 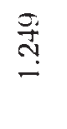 & $\underline{5}$ & $\underset{⿱}{\stackrel{t}{+}}$ & $\underset{\infty}{\stackrel{\mathscr{C}}{\infty}}$ & 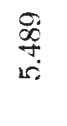 & : \\
\hline & $\begin{array}{l}0 . \\
0 \\
0 \\
0 \\
0 \\
\Sigma \\
\Sigma\end{array}$ & $\begin{array}{c}\text { 总 } \\
\text { 品 } \\
1 \\
1 \\
10\end{array}$ & 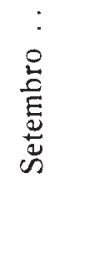 & 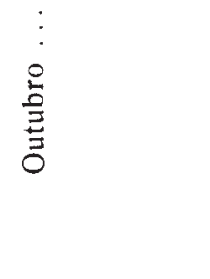 & 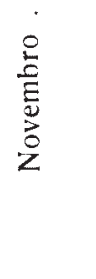 & 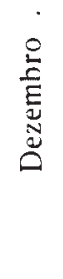 & 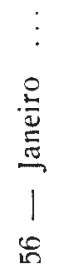 & 离 & $\begin{array}{l}\vdots \\
0 \\
\stackrel{0}{E} \\
\sum\end{array}$ & $\begin{array}{c}\vdots \\
\vdots \\
\bar{\Xi} \\
\dot{E}\end{array}$ & $\begin{array}{c}\vdots \\
\vdots \\
\stackrel{\varrho}{\tilde{m}} \\
\end{array}$ & $\begin{array}{l}\vdots \\
\vdots \\
\stackrel{\circ}{\Xi}\end{array}$ \\
\hline
\end{tabular}




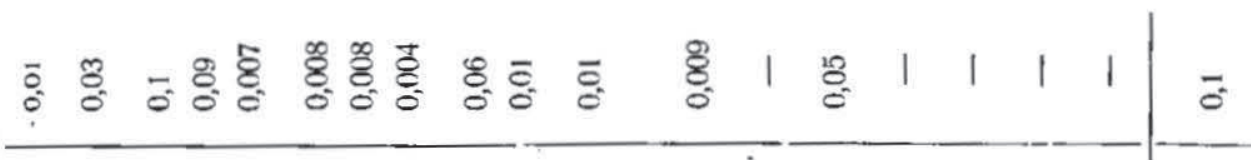

- m nan-an-

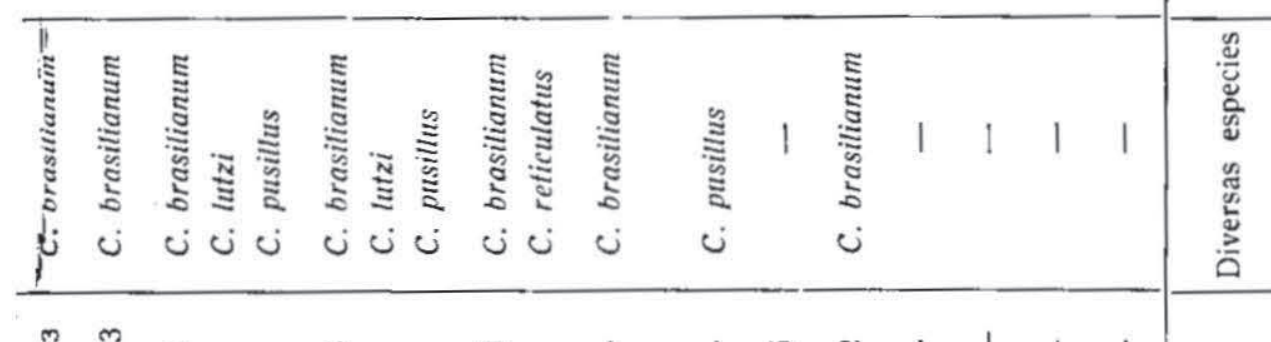

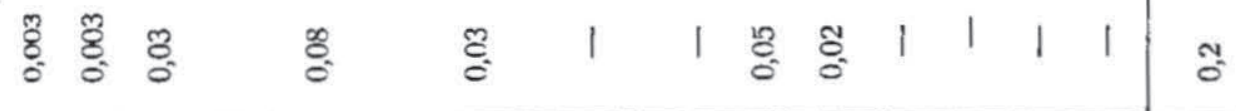

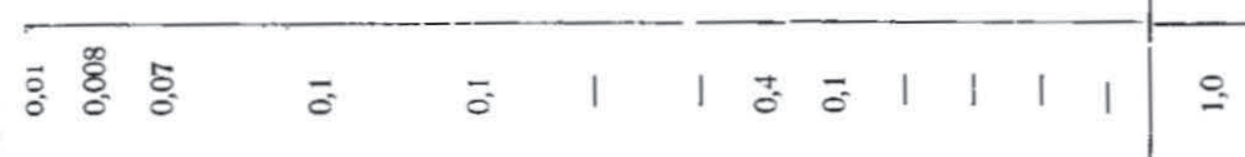

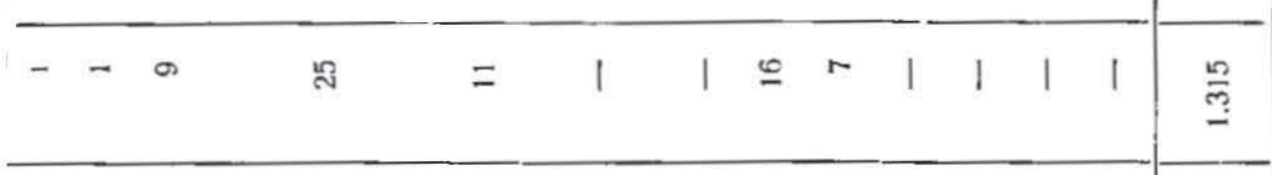

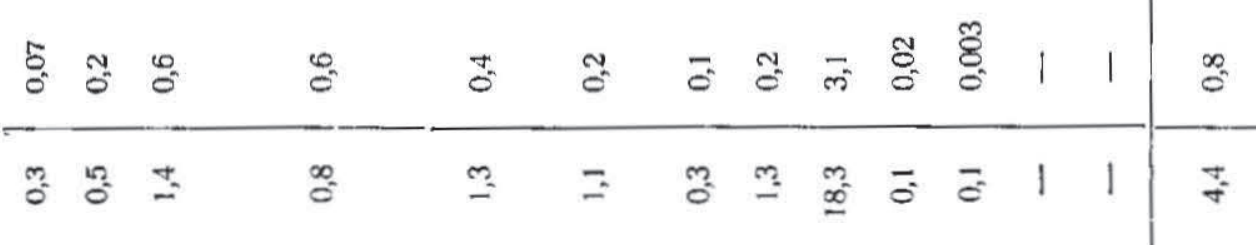

\begin{tabular}{|c|c|c|c|c|c|c|c|c|}
\hline$\approx$ t $\bar{\Phi}$ & 馬 & 吕 & $\Re$ & है & $r-$ & & 1 & 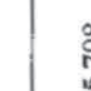 \\
\hline
\end{tabular}

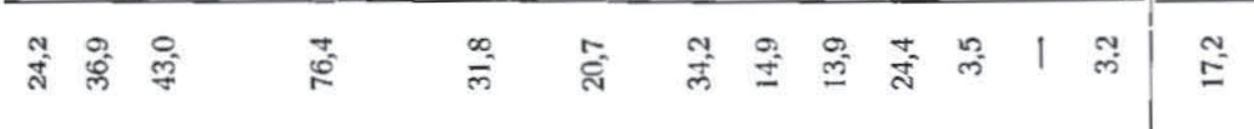

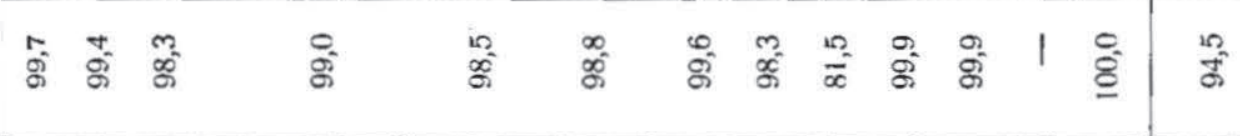

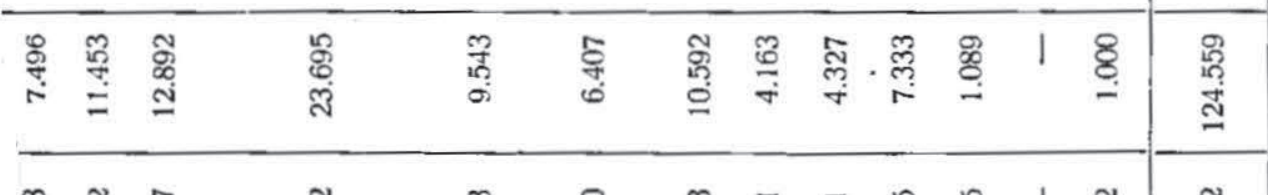

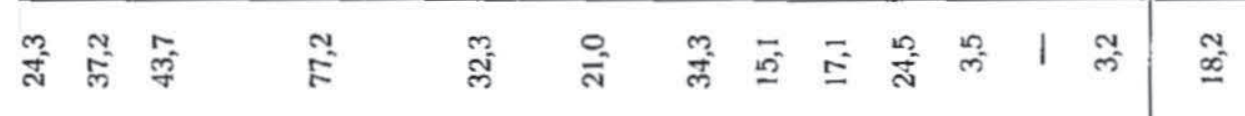

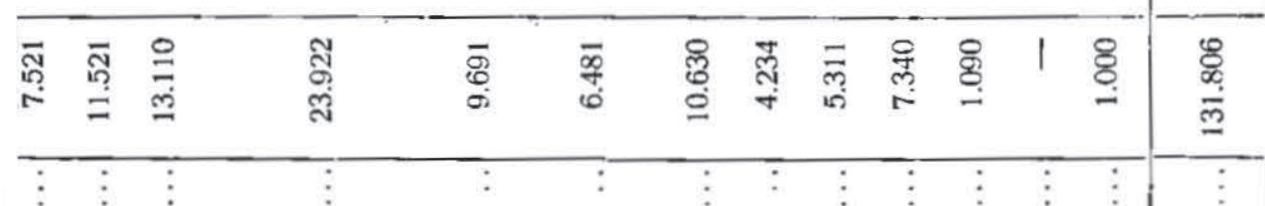

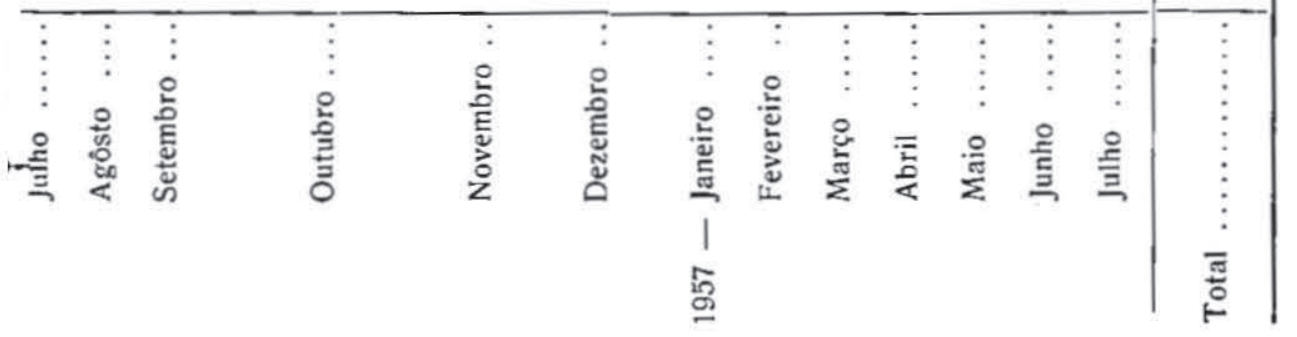




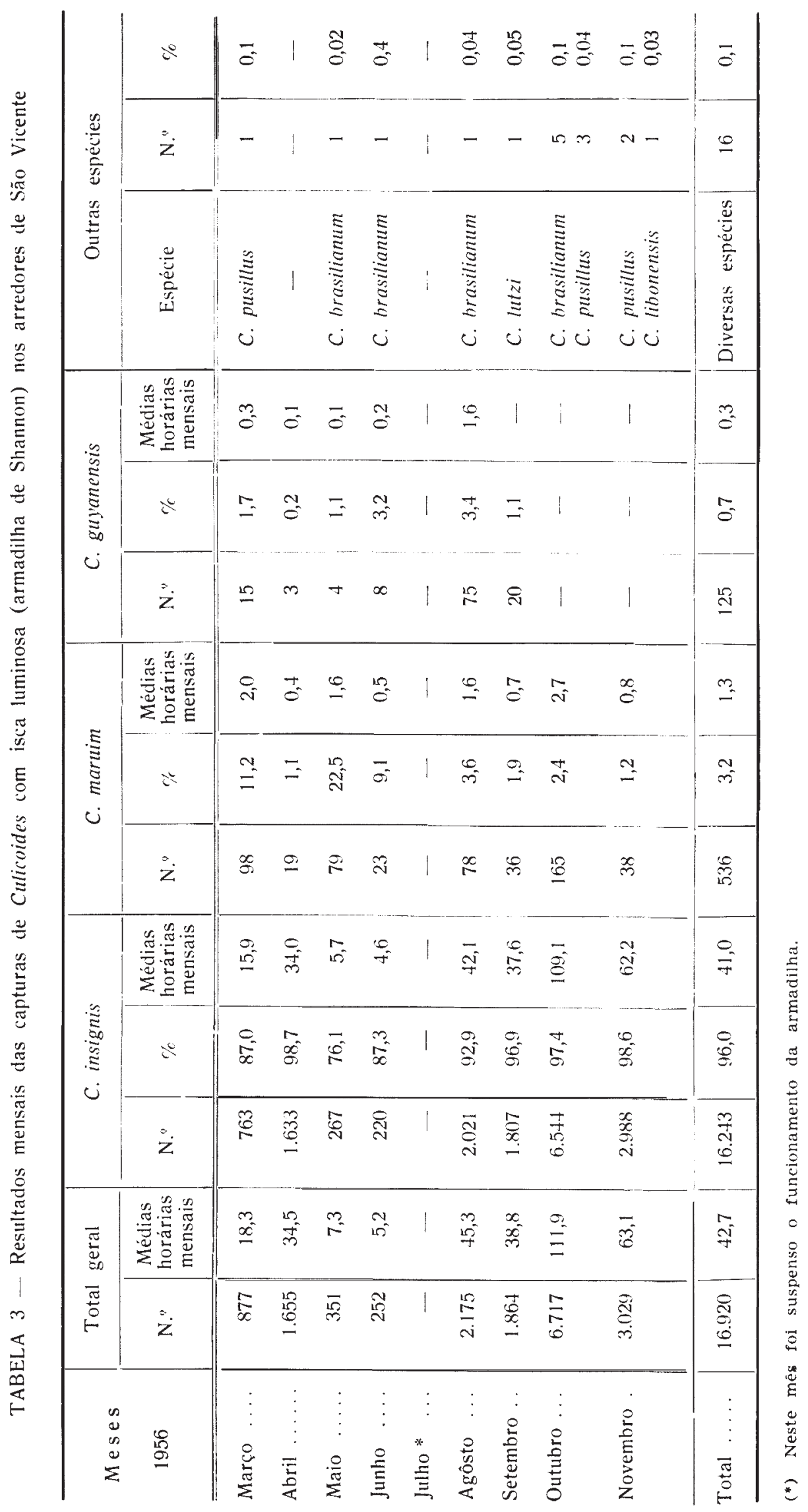


É o que diz respeito às médias horárias mensais que aqui parecem ser maiores do que as obtidas com isca animal. Êste fato poderia indicar certa superioridade dêste tipo de captura, pelo menos em relação a $C$. insignis e C. maruim. Poder-se-ia pois pensar que, em futuras investigações que visem o estudo populacional dessas espécies, êsse tipo de isca deverá ser o escolhido.

\section{Composição especifica}

De agôsto de 1955 a julho de 1957, as duas citadas armadilhas, operando nos arredores da cidade de São Vicente, coletaram um total de $\mathbf{1 4 8 . 7 2 6}$ Culicoides, distribuidos por espécies da seguinte maneira:

\begin{tabular}{|c|c|c|}
\hline C. insignis Lutz, 1913 & 140.802 & $(94,7 \quad \%)$ \\
\hline C. martuim Lutz, 1913 & 6.334 & $(4,2$ \\
\hline C. gulyanensis Floch e Abonnenc, 1942 & 1.440 & $(0,9$ \\
\hline C. brosilianum Forattini, 1956 & 101 & $(0,06 \%)$ \\
\hline C. Lutzi Costa Lima, 1937 & 16 & $(0,01 \%)$ \\
\hline C. reticulatus Lutz, 1913 & 15 & $(0,01 \%)$ \\
\hline C. pusillus Lutz, 1913 & 9 & $(0,006 \%)$ \\
\hline C. flavivenula Costa Lima, 1937 & 4 & $(0,003 \%)$ \\
\hline C. furens Poey, 1853 & 3 & $(0,002 \%)$ \\
\hline C. limonensis Ortiz e León, 1955 & 2 & $(0,001 \%)$ \\
\hline & 148.726 & $(99,9$ \\
\hline
\end{tabular}

Verificamos que, indiscutivelmente, o $C$. insignis constitui a espécie predominante, compreendendo cêrca de $95 \%$ do total obtido. É espécie de grande distribuição na Região Neotropical. Mostra-se muito ativa, picando o homem e animais. Dada a sua pequena exigência no que concerne a locais de criação, tem a faculdade de ampliar consideràvelmente sua distribuição. Encontramo-la freqüentando os domicílios e alí exercendo ativamente seu hábito hematófago. Quanto à espécie $C$. maruim é, como já tivemos ocasião de mencionar, a que merece realmente, a denominação de "mosquitinho do mangue", pois cria-se e habita o terreno pantanoso marinho, com pouca tendência a dêle se afastar. Encontramo-la freqüientando casas dispostas nas vizinhanças do "mangue" mas, de qualquer forma, a sua atividade diminui muito à medida que aumenta a distância em relação aos pantanais de água salgada. O C. guyanensis, embora também pareça não possuir exigências restritas quanto aos criadouros, é espécie pouco abundante em geral. Todavia, em certas ocasiões obtém-se boa produção de adultos, quando então pode se verificar que é bastante ativa na sua hematofagia. As outras espécies são raras, e as observações que pudemos 
levar a cabo não vão além do fato de assinalar-lhes a presença. Interessante se nos afigura o encontro de $C$. furens que, dessa maneira, marca o ponto mais meridional de sua distribuição geográfica conhecida até o presente momento.

Em resumo, três são as espécies mais freqüentes nos arredores de São Vicente, a saber: C. insignis, C. maruim e C. guyanensis. A primeira é absolutamente dominante enquanto que as outras duas entram em pequena percentagem na composição da população local. O C. maruim habita essencialmente o "mangue", onde tem seus locais de criação, atacando o homem e animais que freqüentam êsses terrenos pantanosos. A terceira espécie, torna-se abundante em certas ocasiões, quando pode ser observada em intensa atividade hematófaga. Tôdas as três podem ser encontradas, em atividade, dentro das habitações humanas, desde que tais habitações não estejam em situação desfavorável em relação aos locais de criação.

\section{RESUMO}

Os autores apresentam os resultados de suas observações sôbre a biologia de Culicoides, levadas a efeito nos arredores da cidade de São Vicente, Estado de São Paulo, Brasil. Inicialmente, descrevem a região estudada e os métodos utilizados. Passam depois a relatar os dados obtidos na investigação de criadouros, observando que $C$. insignis cria-se em valas de rua, em terreno pantanoso marinho e em buracos de carangueijos Oedipleura cordata, além de outros criadouros como pequenas coleções de água empoçada em irregularidades do terreno. O C. maruim foi sòmente encontrado nos "mangues" e o $C$. guyanensis em valas de ruas com ou sem teor salino. Encontraram ainda o C. reticulatus criando-se em buracos de carangueijos Cardisoma guanhumi ("guaimú"). Passando ao relato das observações sôbre o comportamento dos adultos, os autores fornecem alguns dados sôbre a freqüência domiciliar e hematofagia. Analisam a seguir, a influência das marés, chegando à conclusão de que as baixas marés influiriam na densidade de algumas espécies, principalmente $C$. maruim. Fornecem, a seguir, dados sôbre a variação estacional, concluindo pela observação de certa tendência à diminuição nos meses frios e secos e aumento nos quentes e chuvosos. Todavia, chamam a atenção para a grande variação e as numerosas discrepâncias observadas, que fazem supor a ação de múltiplos fatôres, gerais e específicos. Terminando, fornecem dados sôbre a composição específica, evidenciando a predominância de $C$. insignis, a pequena abundância de $C$. maruim e $C$. guyanensis e a raridade das demais espécies. Foram encontradas 10 espécies. Os autores julgam interessante assinalar a localidade de São Vicente como limite meridional, até agora conhecido, da distribuição geográfica de $C$. furens. 


\section{SUMMARY}

The authors give the results of their observations on the biology of Culicoides at São Vicente, State of São Paulo, Brazil. In the first place they describe the region and methods used. In their investigation of breeding places the results were as follows: $C$. insignis breeds in ditches, salt marshes, in crab holes of Oedipleura cordata; $C$. maruim was only found in salt marshes; $C$. guyanensis was found in ditches with or without saline concentration; C. reticulatus was found in crab holes of Cardisoma guanhumi. As to adult behaviour, they give some data on house frequenting habits, blood sucking habits and variations of density. They analyse the influence of tides, concluding that low tides may influence the density of some species, chiefly $C$. maruim. The stational variation of density leads to the conclusion that there is a tendency to decrease in cold and dry months and to increase in humid and warm ones. Nevertheless the authors call attention to the considerable variations which lead us to supose the influence of many other general and specific factors. In the end they give some data on the specific composition of the populations studied. The most common species was $C$. insignis and the most rare $C$. maruim and $C$. guyanensis. A total of ten species was found. The authors also report the locality of São $V$ icente as the most southern record of $C$. furens known at present.

\section{BIBLIOGRAFIA}

1. Beck. E. C.: A population study of the Culicoides of Florida (Diptera: Heleidae). Mosquito News, 18:6-11, 1958.

2. Bequaert. J.: Report of an entomological trip to the Truxillo Division, Hon duras. to investigate the sand-fly problem. Ann. Rep. Init. Fruit Co. Med. Dept. 13:197-206, 1924.

3. Carpenter. S. J.: Studies of Culicoides in the Panama Canal Zone (Diptera, Heleidae). Mosquito News. $11: 202-8,1951$.

4. Carter. H. F., Ingram. A. \& Macfie, J. W. S.: Observations on the Ceratopogonine midges of the Cold Coast with descriptions of new species. Part I. Ann. Trop. Med. Parasit. 14:187-210, 1920.

5. Davis. D. E.: A comparison of mosquitoes captured with an avian bait at different vegetational levels. Rev. Ent. 15:209-15, 1944.

6. Dove. W. E., Hall. D. G. \& Hull, J. B.: The salt marsh sand fly problem. Ann. Ent. Soc. Am. 25:505-27, 1932.

7. Foote. R. H. \& Pratt, H. D.: The Culicoides of the Eastern United States (Diptera. Heleidae). Publ. Hlth Monogr. n. 18, 1954. 53 p.

8. Forattini. O. P.: Alogumas observações sôbre hiologia de flebótomos (Diptera, Psychodidae) em região da hacia do Rio Paraná (Brasil). Arq. Fac. Hig̣. S. Púlıl. Univ. S. Paulo, 8:15-136, 1954. 
9. Forattini, O. P. \& Rabello, E. X.: As formas imaturas de Culicoides guayanensis Floch e Abonnenc, 1942, e de algumas espécies de Stilobezzia (Diptera, Ceratopogonidae). Rev. Bras. Ent. 6:43-50, 1956.

10. Forattini, O. P., Rabello, E. X. \& Pattoli, D.: Nota sôbre a larva e pupa de Culicoides insignis Lutz, 1913 (Diptera, Ceratopogonidae). Rev. Bras. Ent. 4: 195-8, 1956.

11. Forattini, O. P., Rabello, E. X. \& Pattoli, D.: A brief note on breeding places of Culicoides in São Vicente, Brazil. Mosquito News, 17:312-3, 1957.

12. Forattini, O. P., Rabello, E. X. \& Pattoli, D.: Sôbre as formas imaturas de Culicoides reticulatus Lutz e de Stilobezzia panamensis Lane e Forattini (Diptera, Ceratopogonidae). Rev. Bras. Ent. Em publicação, 1957.

13. Fox, I: The respiratory trumpet and anal segment of the pupas of some species of Culicoides (Diptera, Ceratopogonidae). Puerto Rico J. Publ. Hlth Trop. Med. 17:412-25, 1942.

14. Fox, I.: Light trap studies on Culicoides in Puerto Rico. J. Econ. Ent. $45: 888-9,1953$.

15. Fox, I. \& Kohler, C. E.: Distribution and relative abundance of the species of biting midges or Culicoides in Eastern Puerto Rico, as shown by light traps. Puerto Rico J. Publ. Hlth Trop. Med. 25:342-9, 1950.

16. Fox, I. \& Maldonado Capriles, J.: Light trap studies on mosquitoes and Culicoides in Western Puerto Rico. Mosquito News, 13:165-6, 1953.

17. Glick, P. A.: Collecting insects by airplane in southern Texas. U.S. Dept. Agriculture Techn. Bull. n. 1158, 1957. 28 p.

18. Haddow, A. J. \& Dick, G. W. A.: Matches of hiting Diptera in Uganda with anaesthetized Monkeys as bait. Ann. Trop. Med. Parasit. 42: 271.7, 1948.

19. Hill, M. A.: The life-cycle and habits of Culicoides impunctatus Coetghebuer and Culicoides obsoletus Meigen, with some observations on the lifecycle of Culicoides odibilis Austen, Culicoides pallidicornis Kieffer, Culicoides cubitalis Edwards and Culicoides chiopterus Meigen. Ann. Trop. Med. Parasit. 41 :55-115, 1947.

20. Hull, J. B., Dove, W. E. \& Prince, F. M.: Seasonal incidence and concentrations of sand fly larvae, Culicoides dovei Hall, in salt marshes (Ceratopogonidae, Diptera). J. Parasit. 20:162-72, 1934.

21. Karstad, L. H. et al.: Eastern equine encephalomyelitis virus isolated from three species of Diptera from Georgia. Science, 125:395-6, 1957.

22. Khalaf, K.: The Culicoides of the Wichita Refuge, Oklahoma. Taxonomy and seasonal incidence (Diptera, Heleidae). Ann. Ent. Soc. Am. $45: 348-58,1952$. 
23. Khalaf, K. T.: Light-trap survey of the Culicoides of Oklahoma (Diptera, Heleidae). Am. Midland Nat. 58:182-221. 1957.

24. Kohler, C. E. \& Fox. I.: The relative attractiveness of New Jersey light traps painted (a) green and (b) yellow to Puerto Rican Culicoides. J. Econ. Ent. 44:112-3. 1951.

25. Lane. J.: A hiologia e taxonomia de algumas espécies dos grupos Forcipomyia e Culicoides (Diptera, Ceratopogonidae (Heleidae). Arq. Fac. Hig. S. Púlbl. Univ. S. Paulo. $1: 159-70.1947$.

26. Lutz, A.: Contribuição para o estudo das "Ceratopogoninas" hematofagas encontradas no Brazil. Mem. Inst. Osw. Cruz, 4:1-32, 1912.

27. Lutz. A.: Contribuição para o estudo das Ceratopogoninas hematofagas do Brazil. Mem. Inst. Osw. Cruz, 5: 45.74, 1913.

28. Mirsa. M.: Insectos de interés médico en "Los Chorros", Estado Miranda. Con referencia especial a los dipteros del genero Culicoides Latreille (Nematocera. Ceratopogonidae). Rev. Sanid. Asist. Soc. 18:731-66, 1953.

29. Murray. W. S.: Investigations on the bionomics of Culicoides obsoletus (Meigen) and other biting midges at Mount Solon, Virginia. Mosquito News, 17:77-82. 1957.

30. Nicholas. W. L.. Kershaw, W. E., Keay, R. W. J. \& Zahra, A.: Studies on the epidemiology of filariasis in West Africa, with special reference to the Britsh Cameroons and the Niger delta. III: 'The distribution of Culicoides spp. hiting man in the rain-forest, the forest fringe and the mountain grasslands of the British Cameroons. Ann. Trop. Med. Parasit. 47:95-111, 1953.

31. Painter. R. H.: The biology, immature stages and control of the sandflies (hiting Ceratopogonidae) at Puerto Castilla, Honduras. Ann. Rep. Unit. Fruit Co. Med. Dept. 15:245-62, 1926.

32. Pickard, E. \& Snow. W. E.: Light trap collections of punkies (Family Heleidae. genus Culicoides) McMinn County. Tennessee, April-September 1952. J. Tenn. Acad. Sci. 30:15-8, 1955.

33. Setzer. J.: Contrihuição para o estudo do Clima do Estado de São Paulo. Bol. D. E. R. (S. Paulo). IX-XI, 1943-45.

34. Snow. W. E.: Feeding activities of some blood-sucking Diptera with reference to vertical distribution in hottomland forest. Ann. Ent. Soc. Am. 48:512.21. 1955 .

35. Snow. W. E.. Pickard, F. \& Jones, C. M.: Observations on the activity of Culicoides and other Diptera in Jasper County, South Carolina. Mosquito News. 18:18-21. 1958.

36. Thomsen, L. C.: Aquatic Diptera. Part V - Cerapogonidae. Cornell Univ. Agric. Exp. Sta. Mem. n. 210, 1937. p. 57-80. 
37. Veloso, H. P., Moura, J. V. de \& Klein, R. M.: Delimitação ecológica dos anofelinos do subgênero Kerteszia na região costeira do sul do Brasil. Mem. Inst. Osw. Cruz, 54:517-30, 1956.

38. Williams, R. W.: Observations on the bionomics of Culicoides tristriatulus Hoffman with notes on $C$. alaskensis Wirth and other species at Valdez, Alaska, summer 1949. Ann. Ent. Soc. Am. 44:173-83, 1951.

39. Williams, R. W.: Observations on the bionomics of some Culicoides of Cheboygan County, Michigan (Diptera, Heleidae). Bull. Brook. Ent. Soc. 50:113-20, 1955.

40. Williams, R. W.: Studies on the Culicoides of Baker County, Georgia (Diptera, Heleidae). I. - Preliminary survey and observations. Ann. Ent. Soc. Am. 48:30-4, 1955.

41. Wirth, W. W. \& Bottimer, L. J.: A population study of the Culicoides midges of the Edwards plateau region of Texas. Mosquito News, $16: 256-66,1956$.

42. Woke, P. A.: Observations on Central American Biting midges (Diptera, Heleidae). Ann. Ent. Soc. Am. 47:61-74. 1954. 